\title{
44. AUTHIGENIC Fe-Mn CARBONATES IN CRETACEOUS AND TERTIARY SEDIMENTS OF THE CONTINENTAL RISE OFF EASTERN NORTH AMERICA, DEEP SEA DRILLING PROJECT SITE $603^{1}$
}

\author{
Ulrich von Rad, Bundesanstalt für Geowissenschaften und Rohstoffe \\ and \\ Reiner Botz, Geologisch-Paläontologisches Institut, Universität Kiel²
}

\begin{abstract}
Abundant Fe-Mn carbonate concretions (mainly siderite, manganosiderite, and rhodochrosite) were found in the hemipelagic claystones of Site 603 on the eastern North American continental rise. They occur as nodules, micronodules, or carbonate-replaced burrow fills and layers at a subbottom depth of between $\sim 120$ (Pliocene) and $1160 \mathrm{~m}$ (Albian-Cenomanian). In general, the $\mathrm{Fe}-\mathrm{Mn}$ carbonate concretions form from $\mathrm{CO}_{3}{ }^{--}$produced by the microbiological degradation of organic matter in the presence of abundant $\mathrm{Fe}^{++}$or $\mathrm{Mn}^{++}$and very low $\mathrm{S}^{--}$concentrations. However, there is also some evidence for diagenetic replacement of preexisting calcite by siderite.

The carbon isotope composition of diagenetic $\mathrm{Fe}-\mathrm{Mn}$ carbonate nodules is determined by $\mathrm{CO}_{2}$ reduction during methanogenesis. Carbonate nodules in Cretaceous sediments at sub-bottom depths of 1085 and $1160 \mathrm{~m}$ have distinctly lower $\delta^{13} \mathrm{C}$ values $(-12.2$ and $-12.9 \%$ ) than Neogene siderites, associated with abundant biogenic methane in the pore space $(-8.9$ to $1.7 \%$ between 330 and $780 \mathrm{~m}$ depth). Since no isotopic zonation could be detected within individual nodules, we assume that the isotopic composition reflects more or less geochemical conditions at the present burial depth of the carbonate nodules. Carbonates did not precipitate within the zone of sulfate reduction (approximately 0.01 to $10 \mathrm{~m}$ ), where all of the pyrite was formed. The oxygen isotope composition indicates precipitation from seawater-derived interstitial waters. The $\delta^{18} \mathrm{O}$ values decrease with increasing burial depth from +5.1 to $-1.2 \%$, suggesting successively higher temperatures during carbonate formation.
\end{abstract}

\section{INTRODUCTION}

Deep-sea drilling data have revealed that siderite is quite common in rapidly deposited, organic-matter-rich, hemipelagic mudstones and black shales along the North Atlantic continental margins. For example, siderite has been reported from the mid-Cretaceous black shales and Miocene claystones of Sites 105 and 101 (Leg 11, Lancelot et al., 1972; Jansa et al., 1979), from Cenomanian black, zeolitic, carbonaceous shales of Site 144 (Leg 14, Berger and von Rad, 1972), from the Hauterivian organic-matter-rich prodelta mudstones of Site 397 (Leg 47A, Einsele and von Rad, 1979), and from the Neogene hemipelagic claystones of Site 388 (Leg 44; Benson, Sheridan, et al., 1978; Asquith, 1979). Wada et al. (1982) described calcite, magnesian calcite, dolomite, and rhodochrosite nodules, formed in the methane-rich layer beneath an $\mathrm{H}_{2} \mathrm{~S}$ /methane layer in the Middle America Trench area in the eastern Pacific (Leg 66), and Wada and Okada (1983) the same type of authigenic carbonates from the Japan Trench (Leg 56).

The occurrence of abundant, complex Fe-Mn carbonate (siderite, manganosiderite, rhodochrosite) nodules, burrow fills, and layers in the middle Miocene to Pliocene hemipelagic claystones of lithostratigraphic Subunits

\footnotetext{
I van Hinte, J. E., Wise, S. W., Jr., et al., Init. Repts. DSDP, 93: Washington (U.S. Govt, Printing Office).

2 Addresses: (von Rad) Bundesanstalt für Geowissenschaften und Rohstoffe, Postfach 5101 53, D-3000 Hannover 51, Federal Republic of Germany; (Botz) Geologisch-Paläontologisches Institut, Universităt Kiel, Olshausenstr. 40, D-2300 Kiel, Federal Republic of Germany.
}

IA-IC was a spectacular discovery at Site 603 , drilled on the outermost continental rise off Cape Hatteras, North Carolina. Similar Fe-Mn carbonate concretions were also found in the Eocene radiolarian claystone, in the Coniacian to Maestrichtian variegated claystone, and in the Aptian-Turonian black carbonaceous claystone (see Fig. 1).

In general, siderite $\left(\mathrm{FeCO}_{3}\right)$ is precipitated during "early" diagenesis at slightly negative Eh (about 0.2 to 0.4 $\mathrm{V})$, at intermediate $\mathrm{pH}$ (6 to 8 ), and in the presence of abundant $\mathrm{Fe}^{++}$and high $\mathrm{pCO}_{2}$ (partial pressure of $\mathrm{CO}_{2}$ ), but very low $\mathrm{S}^{--}$concentrations in the pore water (Garrels and Christ, 1965; Berner, 1971). Siderite forms at low $\mathrm{Eh}$ and moderate to low $\mathrm{pS}^{--}$(Fig. 2). In marine sediments, low Eh conditions are normally not associated with high $\mathrm{pS}^{--}$, (i.e., low $\mathrm{S}^{--}$concentration in pore water), because low Eh resulting from anaerobic, bacterial decomposition of organic matter almost always includes the reduction of sulfate to $\mathrm{H}_{2} \mathrm{~S}$ and the precipitation of pyrite (Berner, 1971). However, below the zone of sulfate reduction, high $\mathrm{pS}^{--}$can be expected. Thus, siderite may form in marine sediments below the zone of sulfate reduction, if the $\mathrm{pCO}_{2}$ is high enough (Fig. 3). In Hole $603 \mathrm{C}$, siderite starts to appear below a sub-bottom depth of around $120 \mathrm{~m}$, where the early diagenetic formation of pyrite related to sulfate reduction has probably been completed.

Authigenic rhodochrosite $\left(\mathrm{MnCO}_{3}\right)$ is the pelagic carbonate most resistant to solution. It commonly occurs in sediments deposited slightly below the calcite compensation depth (CCD) in which oxidized (reddish brown) 


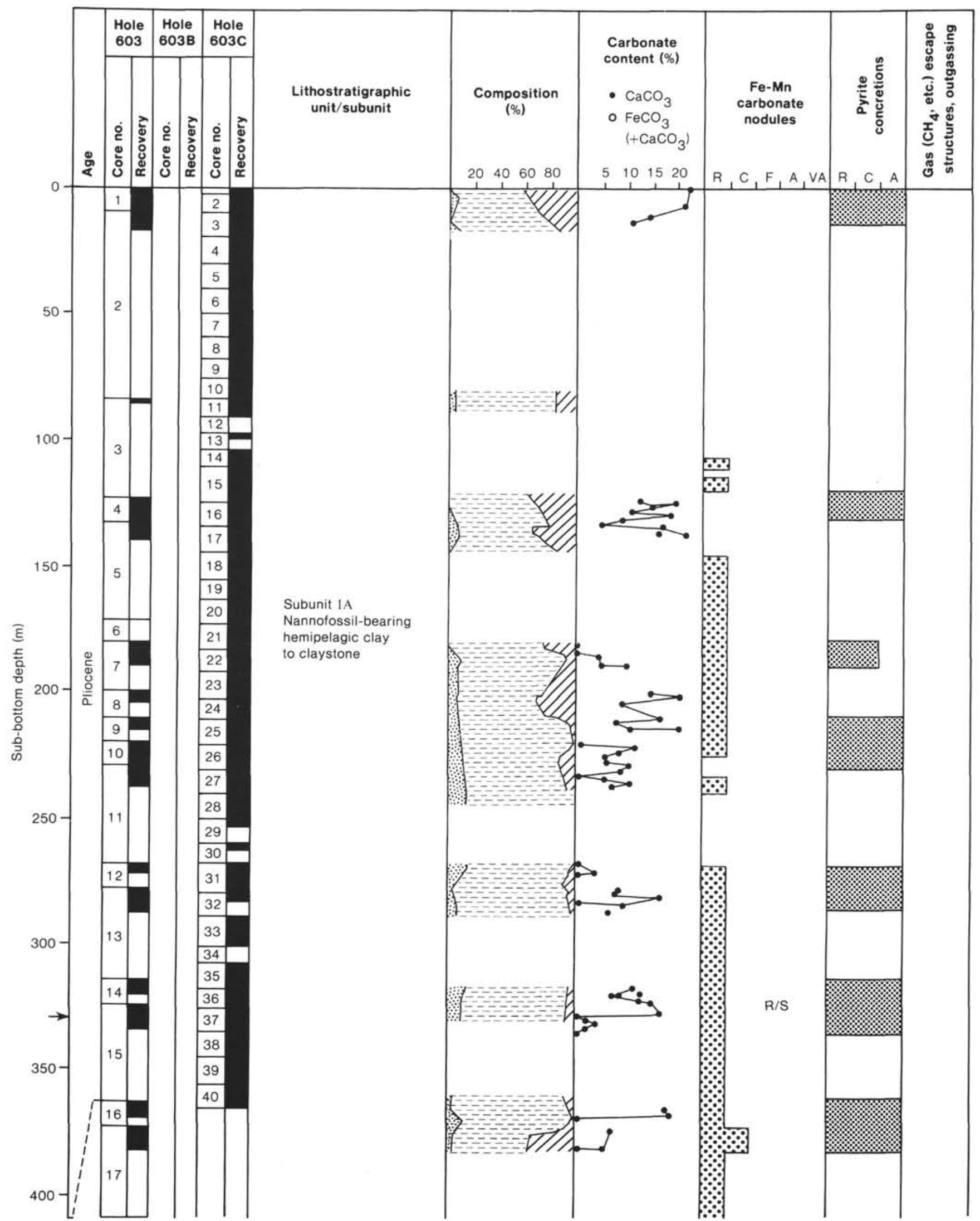

Figure 1. Generalized lithostratigraphy of the upper part of Site 603, also showing the occurrence and abundance of Fe-Mn carbonate nodules, pyrite concretions, carbonate content (shipboard data, P. Meyers), and gas escape structures. Arrows indicate location of investigated authigenic carbonate samples. $\mathrm{R} / \mathrm{S}=$ rhodochrosite/siderite; $\mathrm{T}=$ Turonian. Abundance scale: $\mathrm{R}$, rare $=1-3 ; \mathrm{C}$, common $=4-7 ; \mathrm{F}$, frequent $=8-11 ; \mathrm{A}$, abundant $=12-15$; VA, very abundant $=>15$ siderite layers or nodules per core. 


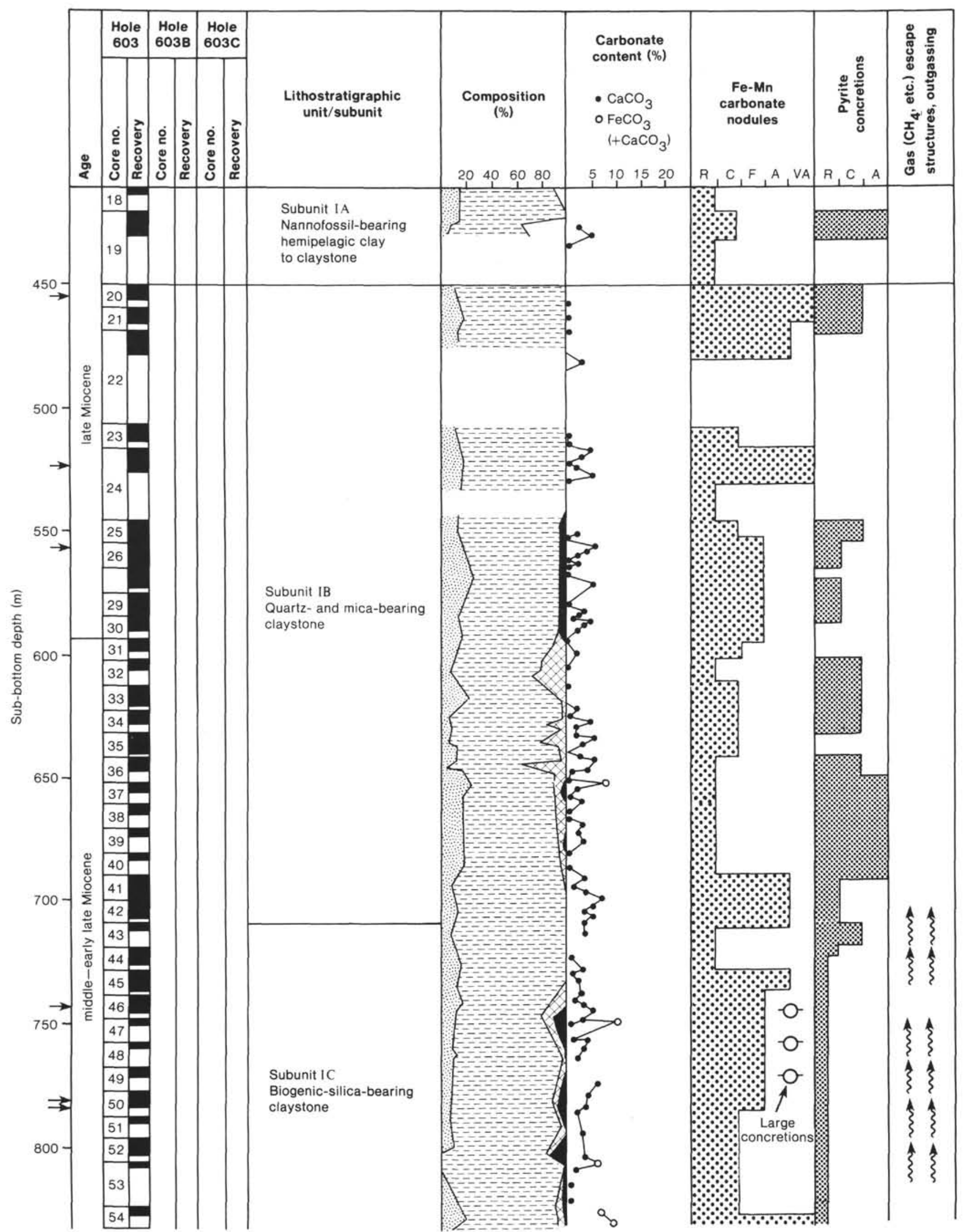

Figure 1 (continued). 


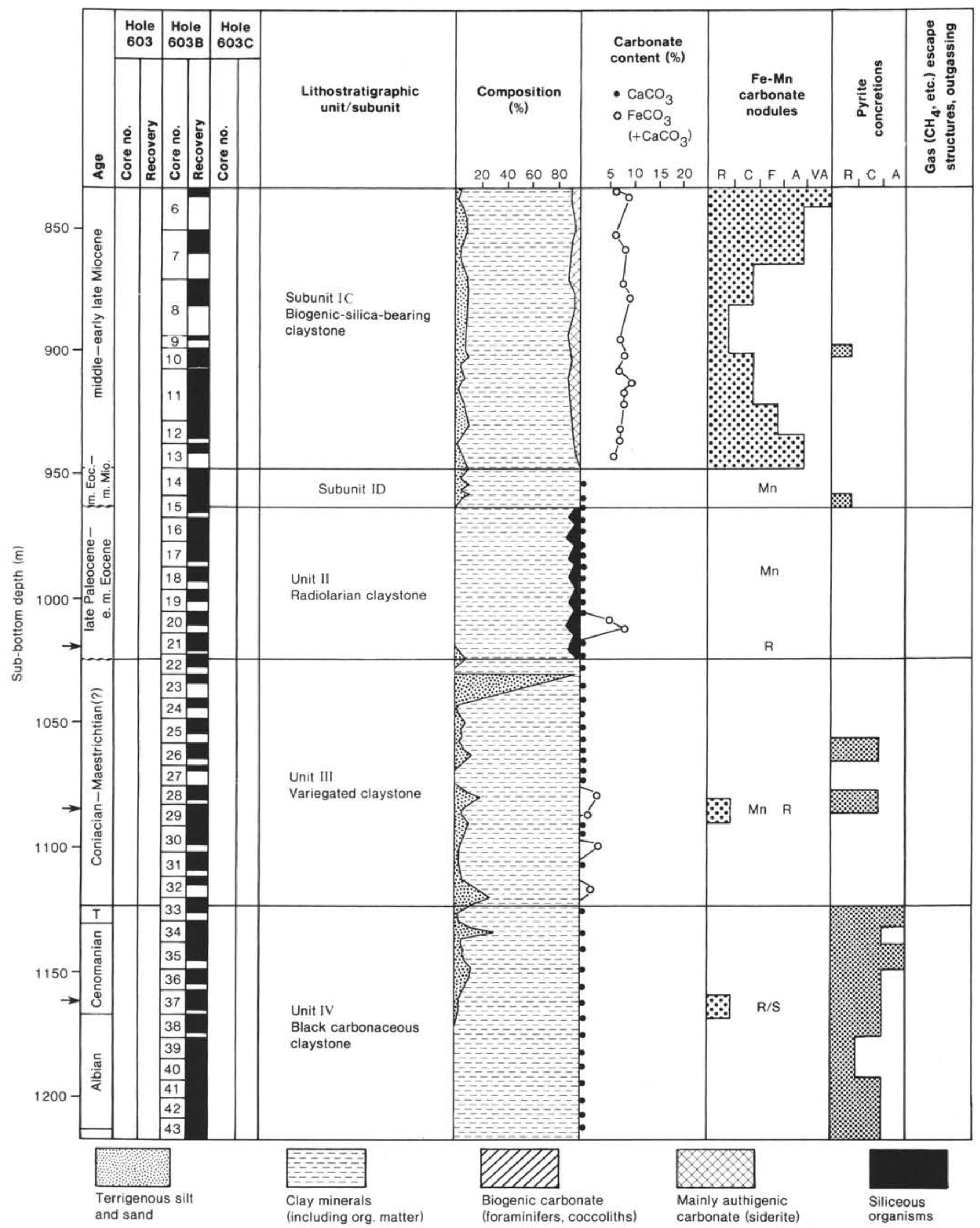

Figure 1 (continued). 


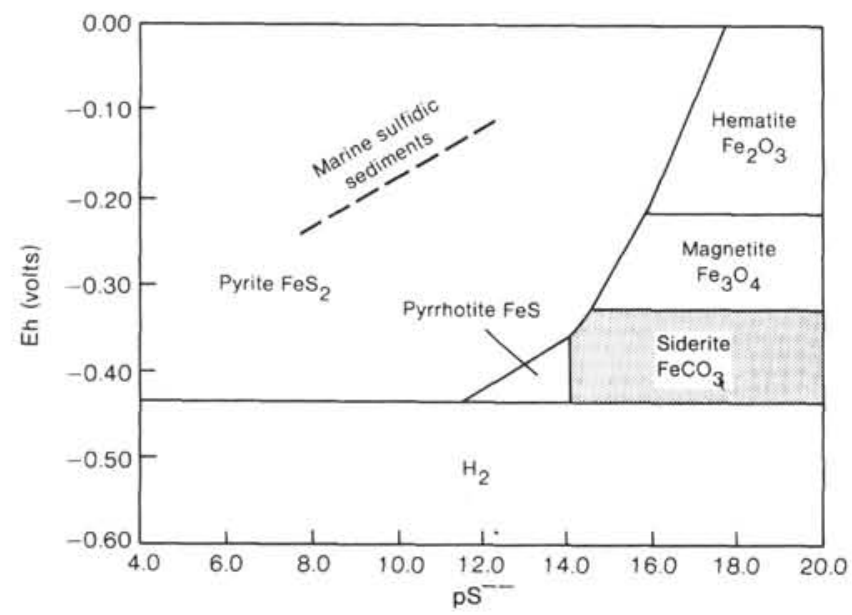

Figure 2. Eh-pS -- diagram for pyrite, pyrrhotite, siderite, and Fe oxides. $\mathrm{pH}=7.37, \log \mathrm{pCO}_{2}=-2.40, \mathrm{~T}=25^{\circ} \mathrm{C}, \mathrm{p}$-total $=1 \mathrm{~atm}$. Natural sulfidic marine sediments fall closely along the dashed line. After Berner (1971).

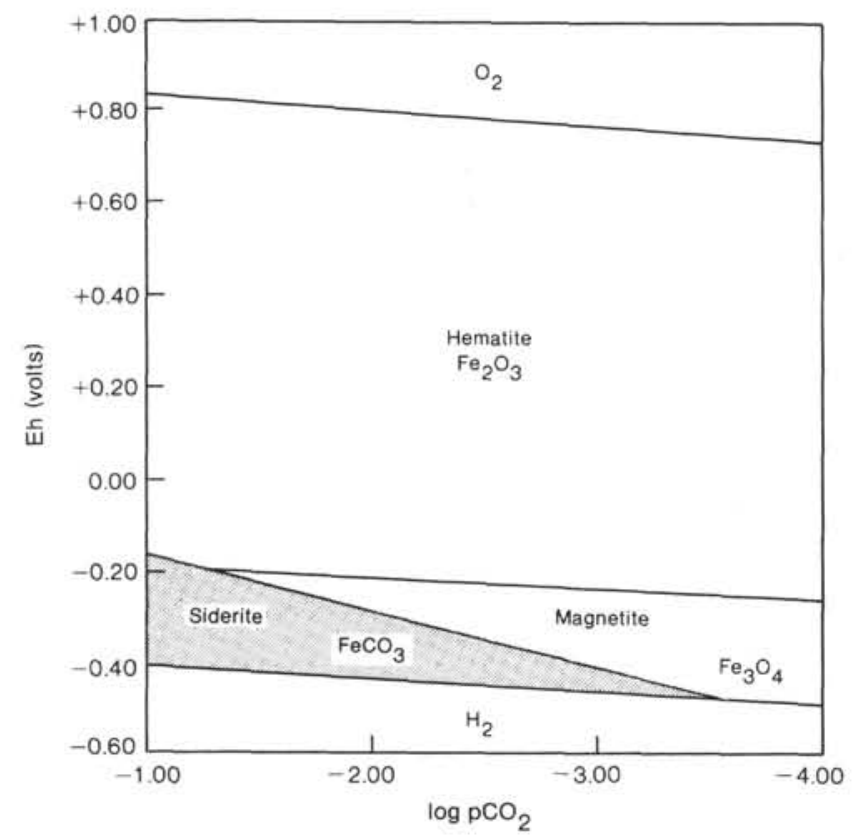

Figure 3. Eh- $\log \mathrm{pCO}_{2}$ diagram for $\mathrm{Fe}$ oxides and siderite in marine sediments. $\mathrm{T}=25^{\circ} \mathrm{C}$, p-total $=1 \mathrm{~atm}, \mathrm{a}_{\mathrm{Ca}}=10^{-2.58}$, equilibrium with calcite assumed. $\mathrm{O}_{2}$ and $\mathrm{H}_{2}$ represent areas where water is thermodynamically unstable relative to the respective gases. The value for $\mathrm{pS}^{--}$is assumed to be so high that pyrite and pyrrhotite do not plot stable (cf. Fig. 2). After Berner (1971).

and partially reduced (greenish gray) sedimentary facies zones alternate (Berger and von Rad, 1972). A prerequisite for its formation is a sufficient supply of organiccarbon-rich (or displaced calcareous) material in the greenish clay facies to reduce the $\mathrm{Mn}^{4+}$ to $\mathrm{Mn}^{++}$and provide the necessary $\mathrm{CO}_{2}$ for the precipitation of $\mathrm{MnCO}_{3}$.

The transitional manganosiderite exists between the end-member carbonates $\left(\mathrm{FeCO}_{3}\right.$ and $\mathrm{MnCO}_{3}$ (Fig. 4). Isomorphous cation substitution (mainly $\mathrm{Fe}, \mathrm{Ca}, \mathrm{Mg}$ ) is

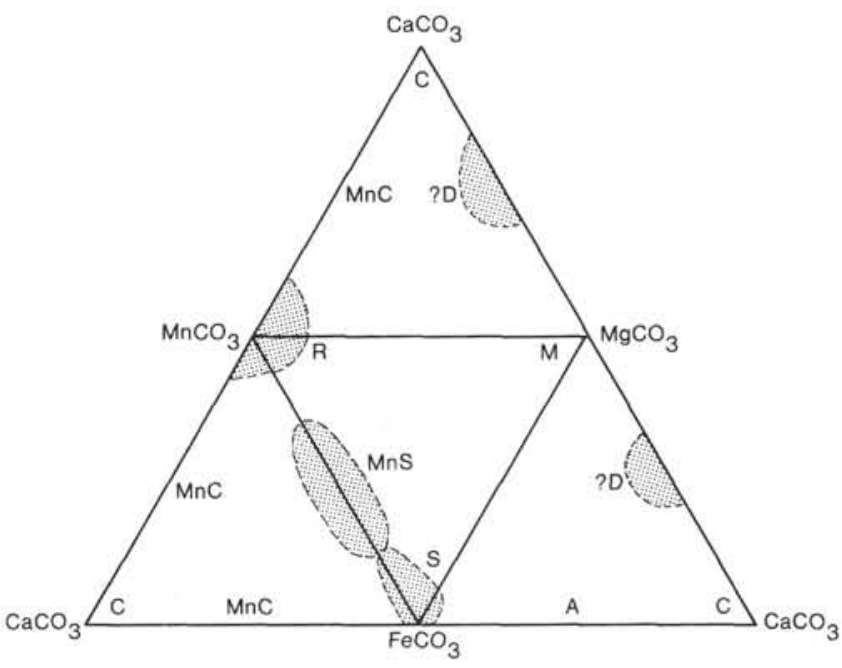

Figure 4. Semiquantitative composition of the authigenic carbonates siderite (S), manganosiderite or oligonite (MnS), dolomite (D) and rhodochrosite (R), investigated in Site 603 cores. Minerals are projected on each face of the $\mathrm{CaCO}_{3}-\mathrm{FeCO}_{3}-\mathrm{MnCO}_{3}-\mathrm{MgCO}_{3}$ tetrahedron (after Tassé and Hesse, 1984). $\mathrm{A}=$ ankerite, $\mathrm{C}=$ calcite, $\mathrm{MnC}=$ manganocalcite (minerals studied in this chapter are shaded).

very common in these minerals (e.g., Tassé and Hesse, 1984).

\section{OCCURRENCE (Table 1, Figs. 1, 5-10)}

Diagenetic Fe-Mn carbonate (mainly siderite) nodules, burrow fills, and discrete layers occur at Site 603 (Holes 603B and 603C), especially in the mid-Miocene to Pliocene hemipelagic claystone of Unit I (Figs. 5 and 6). However, disseminated rhodochrosite also occurs sporadically in the upper Paleocene to mid-Eocene radiolarian claystone Unit II (Fig. 7A), and discrete rhodochrosite layers occur in the Coniacian to Maestrichtian(?) variegated claystone Unit III (Fig. 7B). A manganosiderite nodule was observed in the Aptian-Turonian black carbonaceous claystone Unit IV.

The diagenetic Fe-Mn nodules and layers appear below a burial depth of about $120 \mathrm{~m}$ (Core 603C-15) and become more abundant below a depth of about $450 \mathrm{~m}$, where $\mathrm{CaCO}_{3}$ percentages approach zero (Fig. 1). Two rather indistinct siderite maxima can be noted, one from $400-580 \mathrm{~m}$ and one between about 690 and $950 \mathrm{~m}$, at the base of Subunit IC.

Pyrite concretions are especially abundant from 0 $450 \mathrm{~m}$, between 600 and $700 \mathrm{~m}$, and in the Aptian-Albian black carbonaceous claystone (Unit IV) between 1120 and $1215 \mathrm{~m}$. We note an indistinct negative correlation between the abundance of pyrite and siderite in Site 603, but siderite and pyrite may coexist, because the earlier formed pyrite remains stable at conditions under which only siderite is being precipitated.

At Site 603, authigenic Fe-Mn carbonates occur (1) as scattered, silt-sized, siderite crystals, forming minor admixtures (less than a few percent) in the hemipelagic silty claystones of Unit I; (2) as tiny specks, scattered 
Table 1A. Texture, composition (optical and XRD analysis), and geochemistry of Site $603 \mathrm{Fe}-\mathrm{Mn}$ carbonate samples (see also Fig. 1).

\begin{tabular}{|c|c|c|c|c|c|c|c|c|c|c|c|c|c|c|c|c|c|c|c|c|c|c|c|c|c|c|c|c|c|c|c|c|}
\hline \multirow[b]{2}{*}{$\begin{array}{c}\text { Sample } \\
\text { (interval in } \mathrm{cm} \text { ) }\end{array}$} & \multirow[b]{2}{*}{$\begin{array}{c}\text { Approx. } \\
\text { sub-bottom } \\
\text { depth (m) }\end{array}$} & \multicolumn{2}{|c|}{ Texture } & \multicolumn{6}{|c|}{ Terrigenous } & \multicolumn{5}{|c|}{ Authigenic } & \multicolumn{4}{|c|}{ Biogenic } & \multirow{2}{*}{\multicolumn{2}{|c|}{ 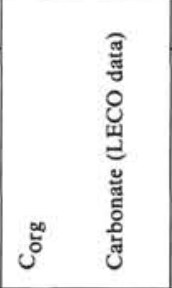 }} & \multicolumn{12}{|c|}{$\mathrm{XRD}$ analysis } \\
\hline & & 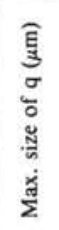 & 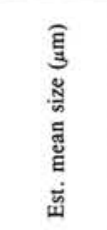 & 壱 & 总 & 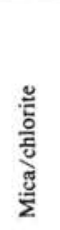 & 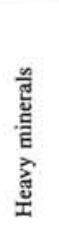 & 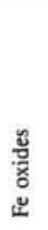 & 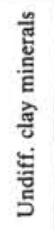 & :ัّ & 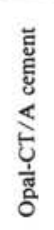 & 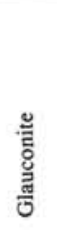 & 茕 & 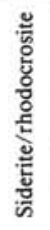 & 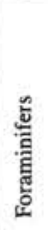 & 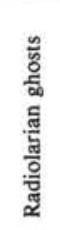 & 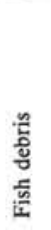 & 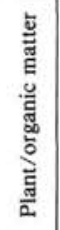 & & & 䓛 & 农 & 茕 & 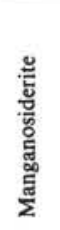 & 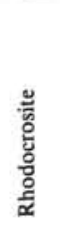 & 䓻 & 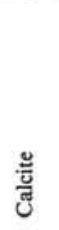 & $\begin{array}{l}\text { 气ّ̆ } \\
\text { Ĕ }\end{array}$ & 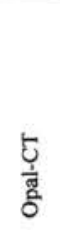 & 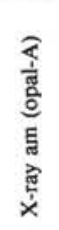 & 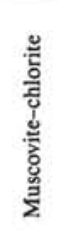 & 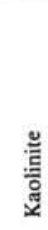 \\
\hline \multicolumn{33}{|l|}{ Hole 603} \\
\hline $15-5,85$ & 330 & & & & & & & & & & & & & & & & & & & & $T$ & & & D & & C & $\mathrm{T}$ & & & & & \\
\hline $20-2,8-10$ & 450 & & & & & & & & & & & & & & & & & & & 62.3 sid & $T$ & & D & & & C & & & & & & \\
\hline $24-6,73-75$ & 525 & & & & & & & & & & & & & & & & & & & & $\mathrm{~T}$ & & D & & & & & $\mathrm{T}$ & & & $\mathrm{T}$ & \\
\hline $26-1,81-83$ & 560 & & sid: $1-2$ & 1 & & & & & 5 & & & & + & 93 & & & & 1 & & & $\mathrm{~T}$ & & D & & & $\mathbf{R}$ & & $\mathrm{T}$ & & & $\mathrm{T}$ & \\
\hline $46-2,56-60$ & 740 & & & $i$ & & & & & 2 & & & & 3 & 92 & $1^{*}$ & 1 & + & & & & $T$ & & D & & & & $\mathrm{T}$ & & & $\mathbf{R}$ & & \\
\hline $50-3,122-124^{\mathrm{a}}$ & 780 & & $q: 5-20$ & 5 & & 2 & & & 83 & & & & 2 & 2 & & 10 & & & & & & & & & & & & & & & & \\
\hline $50-3,122-124^{b}$ & & & & + & & + & & & 4 & & & & 2 & 90 & & $1^{*}$ & & & & & $\mathrm{~T}$ & (T) & D & & & & $\mathbf{R}$ & $\mathrm{C}$ & & & $\mathrm{T}$ & \\
\hline $50-3,128-130^{\mathrm{a}}$ & 780 & & $q: 5-20$ & 5 & & & & & 85 & & & & 5 & & & 5 & & & & & & & & & & & & & & & & \\
\hline $50-3,128-130^{b}$ & & & & 1 & & & & 2 & & & & & & 90 & & 2 & & & & & C & & $\mathrm{C}$ & & & & $\mathrm{T}$ & $\mathrm{C}$ & & & $\mathrm{T}$ & \\
\hline \multicolumn{33}{|l|}{ Hole 603B } \\
\hline $5, C C$ & 831 & 800 & $60-400$ & 45 & 1 & & & & & & $\begin{array}{l}30 \\
\text { (A) }\end{array}$ & 15 & 2 & 5 & 1 & & & + & & & D & & & C & & & $\mathrm{T}$ & & & D & $T$ & \\
\hline $21-4,121-122$ & 1015 & & & 1 & & & & & 59 & & & & & 15 & & 15 & & & 0.4 & $10.2 \mathrm{rh}$ & $\mathrm{T}$ & & & & $R$ & & & A & D & & $T$ & \\
\hline $29-2,41$ & 1085 & 6 & sid: $2-4$ & 1 & & + & & & 2 & & & & & 97 & & & & & 0.2 & $83 \mathrm{rh}$ & $\mathrm{T}$ & & & & D & & & & & & $\mathrm{T}$ & $\mathrm{T}$ \\
\hline $29-2,90$ & 1085 & & & 2 & & 1 & 1 & & 91 & 3 & & & & 2 & & & & & & $2.6 \mathrm{rh}$ & $\dot{T}$ & $\mathbf{R}$ & & & $\mathbf{R}$ & & & D & & & & \\
\hline $37-2,0-5$ & 1160 & & & & & & & & 5 & & & & 1 & 93 & & & & 1 & & & $\mathrm{~T}$ & & & D & & & & $R$ & & & & $\mathrm{~T}$ \\
\hline
\end{tabular}

Note: $\mathrm{am}=$ amorphous matter; $\mathrm{q}=$ quartz; $\mathrm{rh}=$ rhodocrosite; sid $=$ siderite; ${ }^{\bullet}=$ "ghosts". For XRD analysis, $\mathrm{D}=$ dominant $(>25[50] \%) ; \mathrm{A}=$ abundant; $\mathrm{C}=$ common $(>10 \%) ; \mathrm{R}=$ rare; $\mathrm{T}=$ traces $(<10[5] \%) ;(\mathrm{T})=?$ traces. a Silty claystone surrounding nodule.

${ }^{b}$ Siderite nodule. 
Table 1B. Stable isotope composition, SEM data, petrography, and age of Site $603 \mathrm{Fe}-\mathrm{Mn}$ carbonate samples.

\begin{tabular}{|c|c|c|c|c|c|c|c|c|}
\hline \multirow{3}{*}{$\begin{array}{c}\text { Sample } \\
\text { (interval in } \mathrm{cm} \text { ) }\end{array}$} & \multirow{3}{*}{$\begin{array}{l}\text { Analyzed part } \\
\text { of nodule }\end{array}$} & & & \multicolumn{2}{|r|}{ SEM analysis } & \multirow[b]{3}{*}{ Petrography } & \multirow[b]{3}{*}{ Age } & \multirow{3}{*}{$\begin{array}{l}\text { Lithostra- } \\
\text { tigraphic } \\
\text { unit/subunit }\end{array}$} \\
\hline & & \multicolumn{2}{|c|}{$\begin{array}{l}\text { Stable isotopes } \\
\text { (\% } \% \text { PDB) }\end{array}$} & \multirow{2}{*}{$\begin{array}{l}\text { Size of } \\
\text { rhombs } \\
(\mu \mathrm{m})\end{array}$} & \multirow{2}{*}{$\begin{array}{l}\text { Elemental } \\
\text { composition } \\
\text { of diagenetic } \\
\text { carbonates }^{b}\end{array}$} & & & \\
\hline & & $\delta^{13} \mathrm{C}$ & $\delta^{180}$ & & & & & \\
\hline \multicolumn{9}{|l|}{ Hole 603} \\
\hline $15-5,85$ & Bulk & -7.9 & +5.1 & $2-5$ & $\begin{array}{l}\text { Mn-sid: } \mathrm{Fe}>\mathrm{Mn}, \\
\text { ? protodolomite }\end{array}$ & sid nodule & early Pliocene & IA \\
\hline $20-2,8-10$ & $\begin{array}{l}\text { Bulk } \\
\text { Core } \\
\text { Rim }\end{array}$ & $\begin{array}{l}-7.4 \\
-8.9 \\
-7.7\end{array}$ & $\begin{array}{l}+5.7 \\
+5.5 \\
+5.6\end{array}$ & & & $\begin{array}{l}\text { sid concretion } \\
\text { (burrow fill) }\end{array}$ & \multirow{3}{*}{ late Miocene } & \multirow{3}{*}{ IB } \\
\hline $24-6,73-76$ & $\begin{array}{l}\text { Bulk } \\
\text { Core } \\
\text { Rim }\end{array}$ & $\begin{array}{l}-0.2 \\
-0.2 \\
+0.7\end{array}$ & $\begin{array}{l}+4.6 \\
+4.6 \\
+4.7\end{array}$ & & & $\begin{array}{l}\text { Large sid } \\
\text { nodule }\end{array}$ & & \\
\hline $26-1,81-83$ & $\begin{array}{l}\text { Bulk } \\
\text { Core } \\
\text { Rim } \\
\text { Rim }\end{array}$ & $\begin{array}{l}-1.6 \\
-2.8 \\
-3.2 \\
-3.5\end{array}$ & $\begin{array}{l}+4.8 \\
+4.5 \\
+4.5 \\
+4.7\end{array}$ & & & $\begin{array}{l}\text { sid with relict clay } \\
\text { matrix in elongate } \\
\text { flaser structure }\end{array}$ & & \\
\hline $46-2,56-60$ & Bulk & $+1 . \overline{7}$ & +3.8 & $1-5$ & $\begin{aligned} & \text { sid: } \mathrm{Fe} \gg \mathrm{Mn}> \\
& \mathrm{Mg}>\mathrm{Ca} \\
& \text { Coccoliths }\end{aligned}$ & $\begin{array}{l}\text { Clay-min.-pyr-q- } \\
\text { foram. and rad. } \\
\text { ghost-bearing sid } \\
\text { concretion }\end{array}$ & & \\
\hline $50-3,122-124$ & $\begin{array}{l}\text { Bulk } \\
\text { Core } \\
\text { Rim } \\
\text { Rim }\end{array}$ & $\begin{array}{l}+0.6 \\
-0.7 \\
-0.7 \\
-0.6\end{array}$ & $\begin{array}{l}- \\
+3.7 \\
+3.1 \\
+3.3 \\
+3.1\end{array}$ & & & $\begin{array}{l}\text { sid concretion (b) in } \\
\text { silty claystone (a) }\end{array}$ & $\begin{array}{l}\text { Middle to } \\
\text { early late } \\
\text { Miocene }\end{array}$ & IC \\
\hline $50-3,128-130$ & Bulk & +0.8 & +3.9 & $2-7$ & $\begin{array}{l}\text { sid: } \mathrm{Fe} \gg \mathrm{Mg}, \mathrm{Mn}, \mathrm{ca} \\
\text { Coccoliths }\end{array}$ & $\begin{array}{l}\text { q-pyr-sil-org. bearing } \\
\text { clayst. (a) with sid } \\
\text { micronodules (b) }\end{array}$ & & \\
\hline \multicolumn{9}{|l|}{ Hole 603B } \\
\hline $5, \mathrm{CC}$ & & & & & & $\begin{array}{l}\text { Opal-cemented, Mn-sid- } \\
\text { bearing glauc.-rich } \\
\text { sandstone }\end{array}$ & ?middle Miocene & \\
\hline $21-4,121-122$ & Bulk & & & $1-2$ & $\begin{array}{l}\text { rh; lep } \\
\mathrm{Mn} \gg \mathrm{Fe}>\mathrm{Ca}, \mathrm{Mg}\end{array}$ & $\begin{array}{l}\text { rh rad. rich porcella- } \\
\text { neous clayst. }\end{array}$ & $\begin{array}{l}\text { late Paleocene- } \\
\text { early middle Eocene }\end{array}$ & II \\
\hline $29-2,41$ & Bulk & -12.2 & 0 & $5-10$ & $\begin{array}{l}\text { rh } \\
\mathrm{Mn} \gg \mathrm{Ca}, \mathrm{Mg}\end{array}$ & $\begin{array}{l}\text { rh nodule }(3 \mathrm{~mm}) \\
\text { Zeolite- } \mathrm{q} \text {-rh-bearing } \\
\text { claystone }\end{array}$ & $\begin{array}{l}\text { Cenomanian to } \\
\text { Coniacian }\end{array}$ & III \\
\hline $37-2,0-5$ & Bulk & -12.9 & -1.2 & $5-20$ & $\begin{array}{l}\text { Mn-sid } \\
\mathrm{Fe}>\mathrm{Mn},(\mathrm{Ca})\end{array}$ & sid nodule & Aptian/Albian & IV \\
\hline
\end{tabular}

Note: lep = opal-CT lepispheres; $\mathrm{pyr}=$ pyrite; $\mathrm{q}=$ quartz; $\mathrm{rh}=$ rhodocrosite $\left(\mathrm{MnCO}_{3}\right) ;$ sid $=$ siderite $\left(\mathrm{FeCO}_{3}\right) ; \mathrm{Mn}$-sid $=$ manganosiderite $(\mathrm{Mn}, \mathrm{Fe}) \mathrm{CO} 3$.

a Refers to isotopic analysis.

${ }^{b}$ Estimated from energy-dispersive spectral analysis.

crystals, fibroradiated twinned crystals, or micronodules (Fig. 7A; Figs. 9C-E; (3) as nodules or burrow fills, $\sim 0.5-3 \mathrm{~cm}$ in diameter, often concentrated in discontinuous layers (Fig. 5D); (4) as large concretions, $15-20 \mathrm{~cm}$ in diameter (only in cores $603-46$ to -48 ; Fig. 5A, B; Fig. 6A); (5) as discrete, more or less burrowed layers (Fig. 5C); Fig. 6B, top); (6) as layers of many individual (1-3 mm), scattered concretions, probably burrow fills (Fig. 6B).

The small siderite nodules may appear homogeneous. The large siderite nodules or layers, however, invariably show streaked-out burrow structures (Fig. 5C), or even a knobby-botryoidal surface, possibly related to a large burrow, filled by crustacean(?) fecal pellets (Fig. 5A, B). Some siderite concretions have the irregular shape of a branching, tubelike burrow. Figure $6 \mathrm{~B}$ shows two different types of bioturbation structures which were diagenetically sideritized, a 3-cm-thick layer with large, irreg- ular burrows and a 5-cm-thick layer with much smaller (2-5 $\mathrm{mm})$, siderite-filled burrows.

\section{METHODS}

Fe-Mn carbonate concretions found at Site 603 were studied by optical microscopy, X-ray diffraction (XRD), scanning electron microscopy (SEM) using an energy-dispersive X-ray spectrographic attachment, and analysis of stable isotope composition. We investigated nine thin sections to study the texture and composition of siderite/ rhodochrosite nodules and layers (Table 1A, Figs. 8-10).

X-ray diffraction analyses were performed by Dr. H. Rösch (BGR, Hannover) on 12 samples using a Philips X-ray diffractometer (Table 1A). By identifying the (1011) or $d_{104}$ reflecting planes of the authigenic carbonates it was possible to determine the presence of rhodochrosite $\left(2 \theta \mathrm{CuK} \alpha=31.5^{\circ}\right)$ or of siderite $\left(2 \theta \mathrm{CuK} \alpha=32.0^{\circ}\right)$.

An isomorphous mixture of the two end-member carbonates, "manganosiderite" (603B-15-5, $85 \mathrm{~cm}$; 603B-37-2, 0-5 cm), is characterized by a $2 \Theta$ value of $31.8^{\circ}$, corresponding to a Mn-content of up to $9 \%$. An isomorphous partial substitution of $\mathrm{Fe}$ by other cations, for example, $\mathrm{Ca}$ or $\mathrm{Mg}$, may, however, complicate estimation of the carbonate chemistry from XRD analysis (see Fig. 4). Sample 603-15-5, 
A

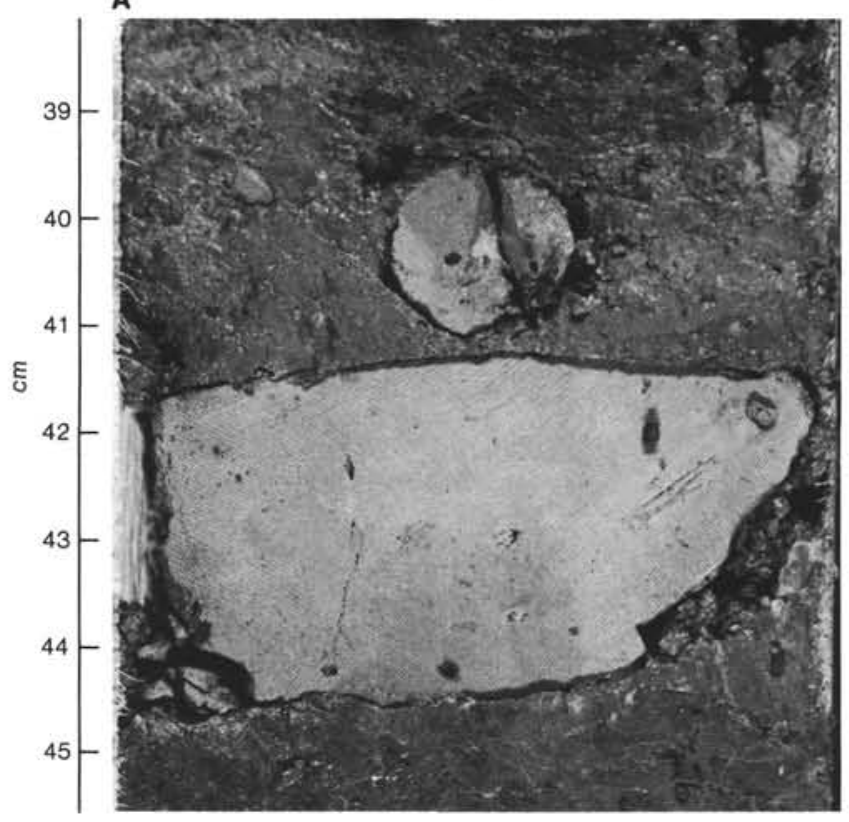

C

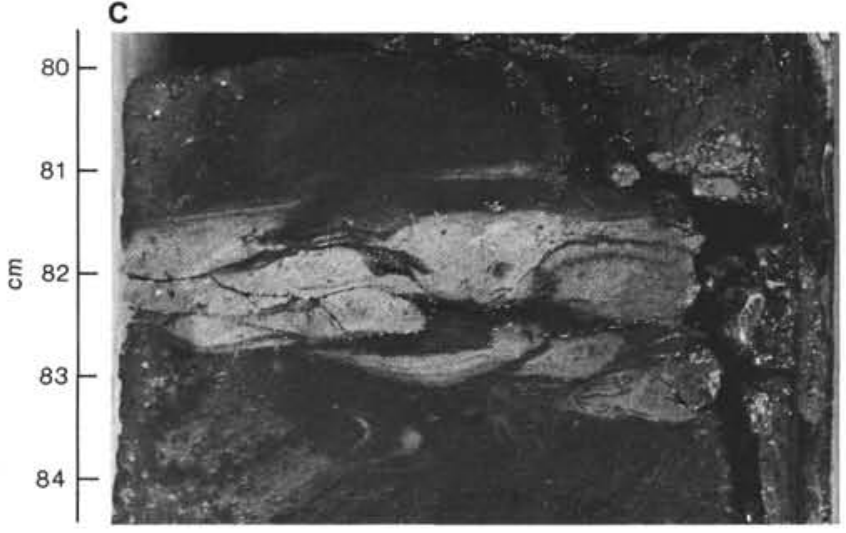

B

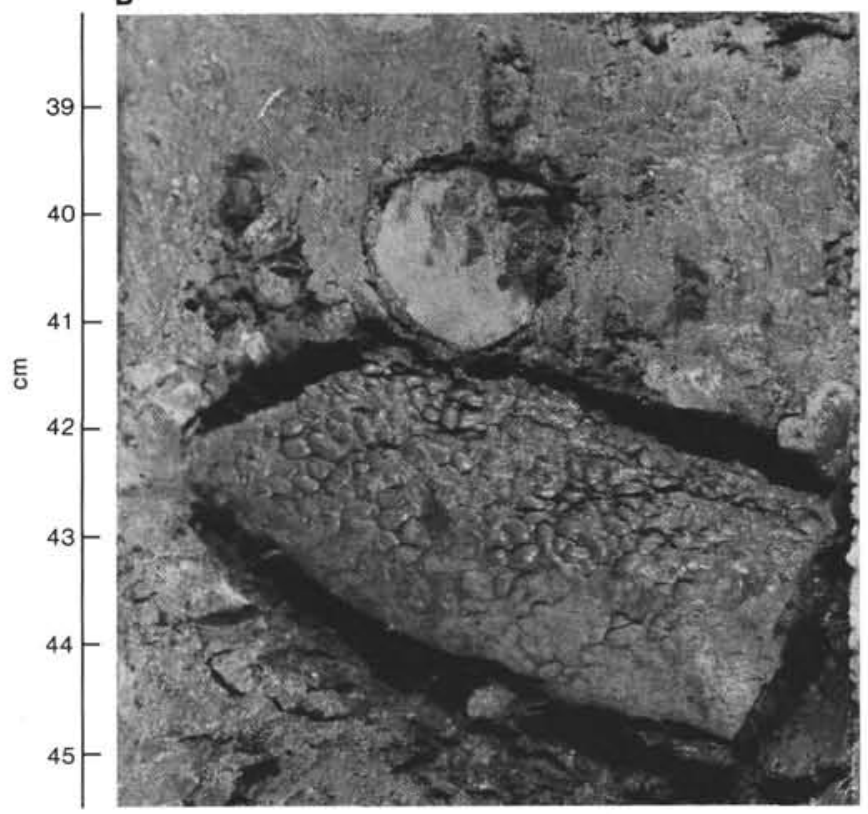

D

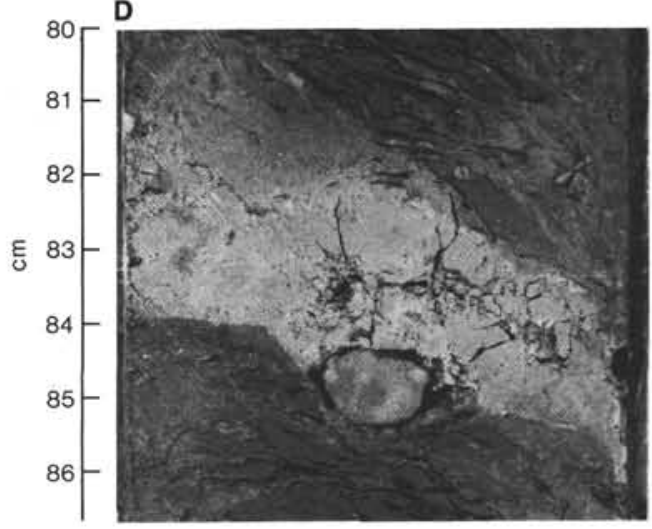

Figure 5. Siderite nodules and layers in the upper Miocene Subunit IB of Site 603. A. Small spherical and large elongate siderite nodules in hemipelagic quartz- and mica-bearing claystone. B. Same nodule as A. Note knobby-botryoidal surface (possibly a large sideritized burrow with fecal pellets from crustaceans), Sample $603-21-1,38-45.5 \mathrm{~cm}$. C. Siderite layer showing bioturbation, Sample 603-26-1, 80-84 cm. D. Discrete siderite layer (or elongate concretion), Sample 603-22-2, 80-86 cm.

$85 \mathrm{~cm}$ contains a dolomite which may be Fe-Mn-rich, as indicated by a shift of the characteristic $2 \theta$ peaks. Sample $603-20-2,8-10 \mathrm{~cm}$ contains stoichiometric dolomite with a $\mathrm{Ca}: \mathrm{Mg}$ ratio of $1: 1$.

Six diagenetic carbonate samples were investigated under a Siemens-ETEC Autoscan scanning electron microscope with an energydispersive X-ray spectrographic attachment to study the elemental composition of the crystals (see Table 1B; Figs. 8, 10).

Stable isotopic $\left(\delta^{18} \mathrm{O}\right.$ and $\left.\delta^{13} \mathrm{C}\right)$ analyses were made from 19 samples (18 siderites, 1 rhodochrosite; see Table 1B). A large piece of the bulk sample was ground and analyzed for all samples. If enough material was available, we also analyzed additional samples, representing the core and the rim of the nodules. The samples were reacted with $100 \%$ phosphoric acid at $80^{\circ} \mathrm{C}$ to produce $\mathrm{CO}_{2}$ gas for isotopic analysis. Applying this method, only the $\delta^{18} \mathrm{O}$ values had to be corrected by $+1.4 \%$ (the $\delta^{13} \mathrm{C}$ values were identical for the standard $\mathrm{CO}_{2}$ collected from the reaction at $25^{\circ} \mathrm{C}$ and $80^{\circ} \mathrm{C}$, respectively). The $\delta^{18} \mathrm{O}$ correction factor of $+1.4 \%$ was determined by reaction of a Solnhofen limestone standard with phosphoric acid at $80^{\circ} \mathrm{C}$, resulting in a $\delta^{18} \mathrm{O}$ value $1.4 \%$ more negative than the $\delta^{18} \mathrm{O}$ value for the same standard reacted at $25^{\circ} \mathrm{C}$. The standard deviation for the isotopic analysis was $0.1 \%$ for carbon and $0.2 \%$ for oxygen. The measurements were carried out with a Varian MAT 250 mass spectrometer.

\section{PETROGRAPHIC AND CHEMICAL RESULTS}

The bulk (90-97\%) of most siderite nodules consists of a homogeneous, equigranular, cryptocrystalline (1-2 $\mu \mathrm{m})$ matrix of siderite, with a few percent of detrital quartz, mica, glauconite, organic matter, and clay minerals. Framboidal pyrite, apparently older than the siderite, may occur in the nodules (Fig. 8B). Sometimes, a few foraminifers (Fig. 8D) or "ghosts" of radiolarian tests replaced by opal-CT may be present.

Sample $603 \mathrm{~B}-5, \mathrm{CC}$ is a glauconite-rich quartz sandstone, with manganosiderite rhombs ( $3 \mu \mathrm{m}$ in diameter) surrounded by a younger opal cement (Fig. 9A, B).

A radiolarian-rich porcellaneous claystone (Sample 603B-21-4, 121-122 cm) contains conspicuous, scattered, fibroradiated twins of rhodochrosite crystals in a silicified (opal-CT) clay matrix (Fig. 9C, D, E; Fig. 10A). We observed euhedral individual crystals (50-300 $\mu \mathrm{m})$, ag- 
A

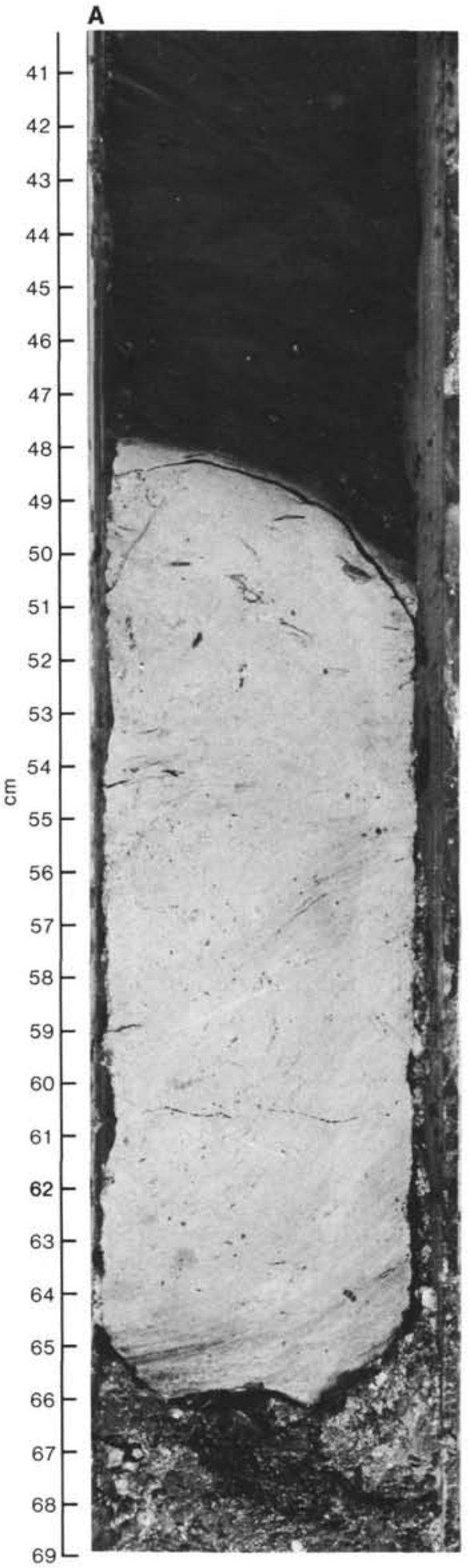

B

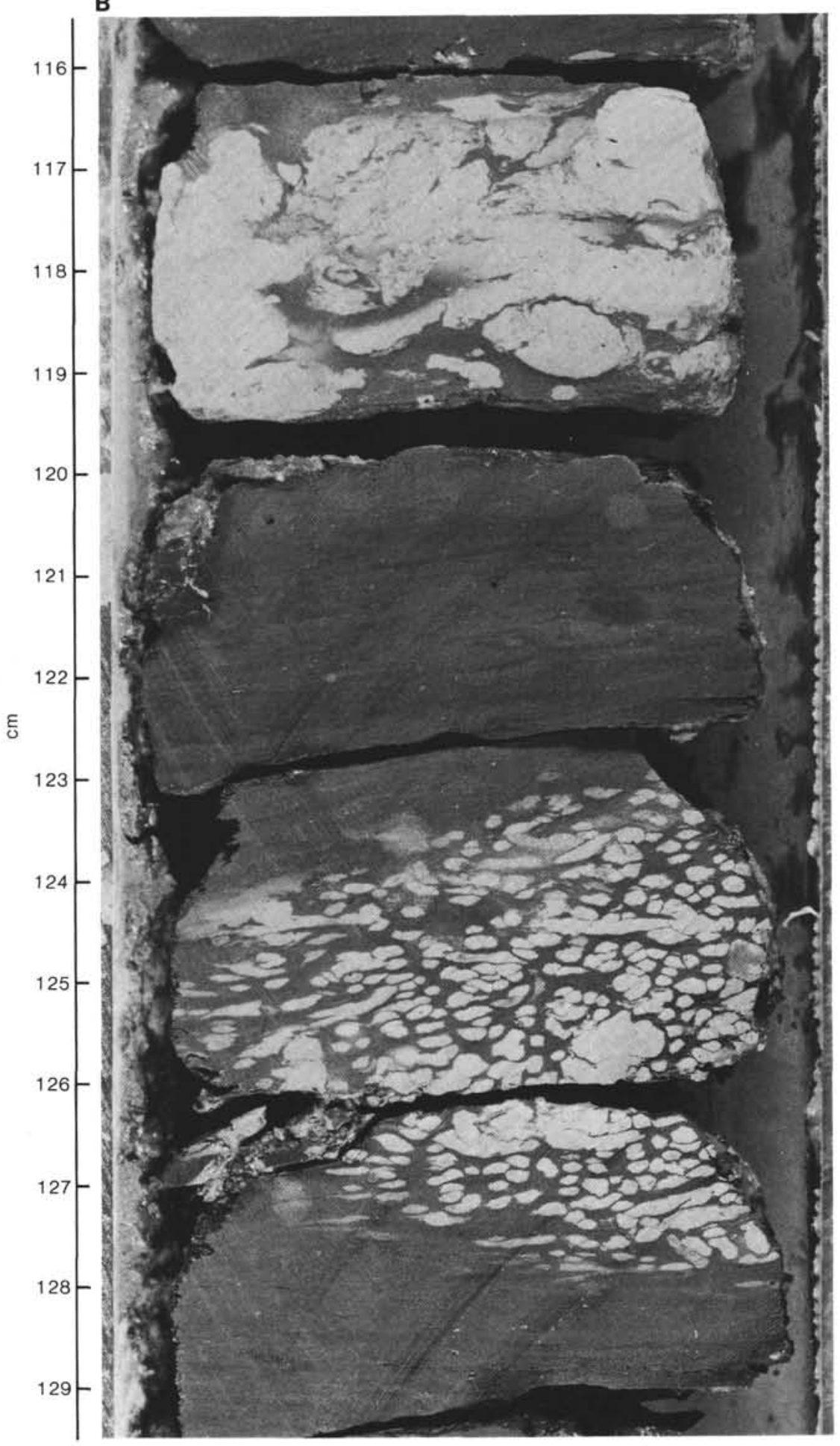

Figure 6. Siderite layers and sideritized burrow structures. A. Thick $(17 \mathrm{~cm})$ siderite layer (or large concretion). Note relict structure of incompletely sideritized claystone at base and bioturbation structures. Sample 603-46-2, 40-69 $\mathrm{cm}$. B. Top shows 3-cm thick, massive, siderite layer with large elongate bioturbation structures. At base, thick layer in which only the 2-5 mm large burrows became sideritized. Sample 603-50-3, 115.5-129.5 cm.

gregates of small crystals $(50 \mu \mathrm{m})$ with a predominantly triangular cross section, and rosette-shaped clusters of crystals (maximum size $>1 \mathrm{~mm}$ ). The rosette-shaped crystals have a dark nucleus from which stalky crystals with subparallel edges grow outward $(\mathrm{H}$. Schmitz, per- sonal communication, 1984). The recrystallization, which resulted in a wavy extinction under crossed nicols, is likely to have occurred before the host sediment was consolidated, as is indicated by the orientation of sediment particles visible under first-order-red illumination. 

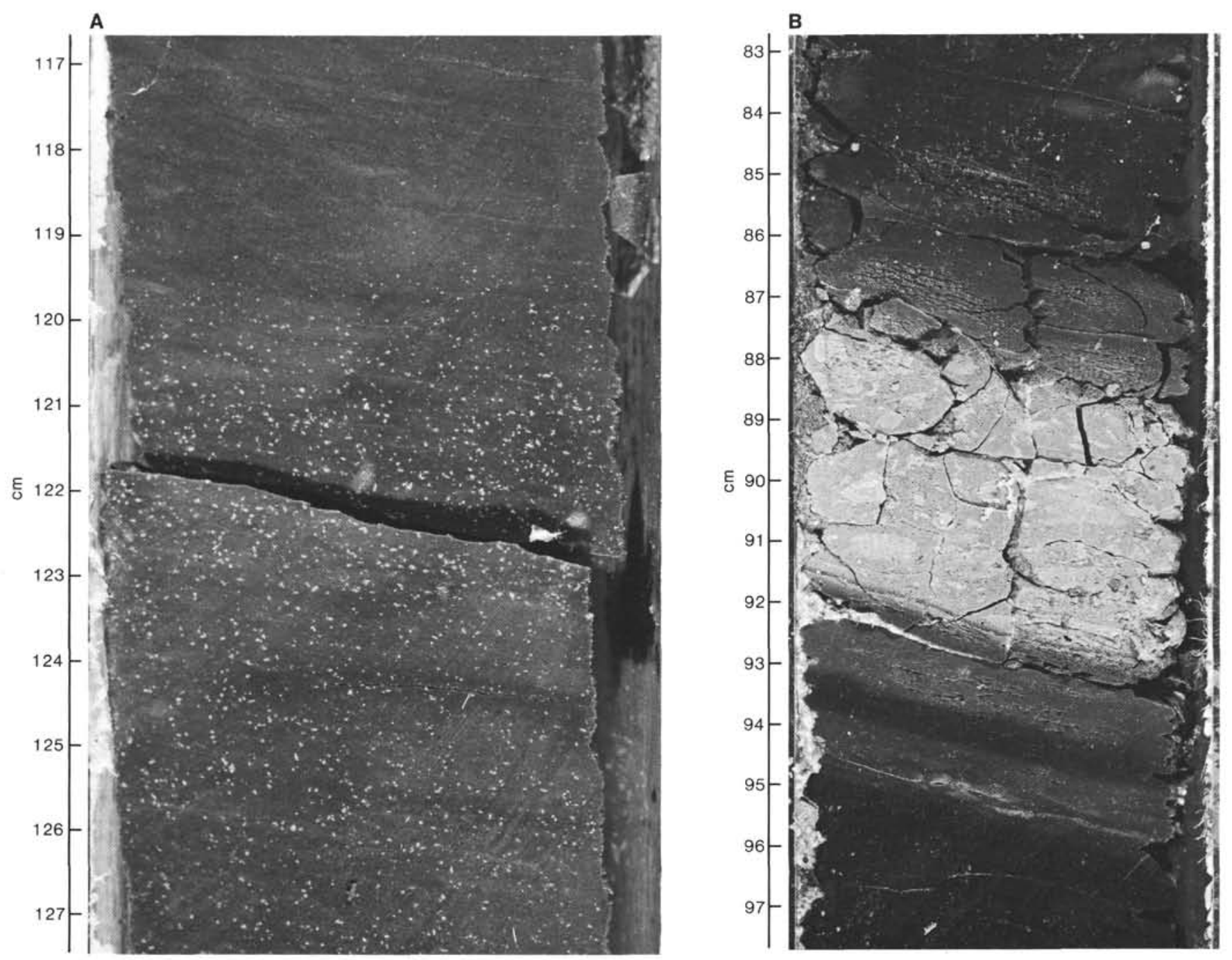

Figure 7. Rhodochrosite. A. Scattered, tiny rhodochrosite crystals (mostly twins, see Fig. 9) in Eocene greenish gray, zeolite-rich, radiolarian claystone, Sample 603B-21-4, 117-127.5 cm. B. Discrete, 4-cm thick, white zeolite-, quartz-, and rhodochrosite-bearing smectite layer (possibly an altered ash) in Cenomanian to Coniacian variegated claystone, Sample 603B-29-2, 83-97.5 cm.

The rhodochrosite nodules (e.g., Sample 603B-29-2, $41 \mathrm{~cm}$; Fig. 10B) have much larger $(5-10 \mu \mathrm{m})$ carbonate rhombs than the siderite nodules. Sample 603B-37-2, $0-5 \mathrm{~cm}$ is a rhodochrosite nodule with a late diagenetic cobblestone-type cement of large $(80 \mu \mathrm{m})$, interlocking, anhedral to subhedral crystals (Fig. 10C, D).

The composition of the carbonate rhombs was semiquantitatively estimated by an energy-dispersive X-ray spectrographic attachment to the SEM (Table 1). "Pure" siderites $\left(\mathrm{FeCO}_{3}\right)$ and rhodochrosites $\left(\mathrm{MnCO}_{3}\right)$ are rare (rhodochrosite: 603B-29-2, $41 \mathrm{~cm}$; siderite: 603-46-2, $56-60 \mathrm{~cm}$ ). The two uppermost samples of Hole $603 \mathrm{con}-$ tain "manganosiderite" and dolomite, according to XRD analysis, although no pure $\mathrm{Ca}-\mathrm{Mg}$ carbonate could be verified under the SEM (Table 1). However, some carbonate rhombs have the general composition $\mathrm{Fe}>\mathrm{Mg}$ $>\mathrm{Ca}, \mathrm{Mn}$, whereas most rhombs appear to be manganosiderite (with $\mathrm{Fe}>\mathrm{Mn}>\mathrm{Mg}, \mathrm{Ca}$ ). Most other samples consist of isomorphous mixtures of the Fe-Mn carbonate series, that is, manganosiderite with $\mathrm{Fe}>\mathrm{Mn}$ (Fig. 4).
It is now well established that complex, marine, authigenic carbonates form preferentially in organic-matter-rich sediments, which were either deposited under anoxic conditions or became reducing shortly after sedimentation, and in which $\mathrm{Mn}$ and $\mathrm{Fe}$ oxides and hydroxides were remobilized in the reducing diagenetic environment of the methanogenetic zone (Wada et al., 1982; Gautier, 1982; Wada and Okada, 1983; Tassé and Hesse, 1984). To form the authigenic carbonates siderite, manganosiderite, and rhodochrosite, high $\mathrm{Fe}^{++}$and $\mathrm{Mn}^{++}$ concentrations in the pore water, a high bicarbonate alkalinity, and a very low $\mathrm{S}^{--}$concentration are required. Sulfide disappears below the bacterial sulfate reduction zone (Fig. 11), where most of the $\mathrm{S}^{--}$is used up by the precipitation of pyrite. High interstitial metal concentrations, especially $\mathrm{Fe}^{++}$and $\mathrm{Mn}^{++}$, are typical for hemipelagic sediments in which terrigenous $\mathrm{Fe}$ oxides and hydrogenetic or diagenetic $\mathrm{Mn}$ oxides were remobilized in a reducing diagenetic environment. The high $\mathrm{CO}_{3}{ }^{--}$concentrations in the pore waters usually result from the degradation of organic matter, although the dissolution 

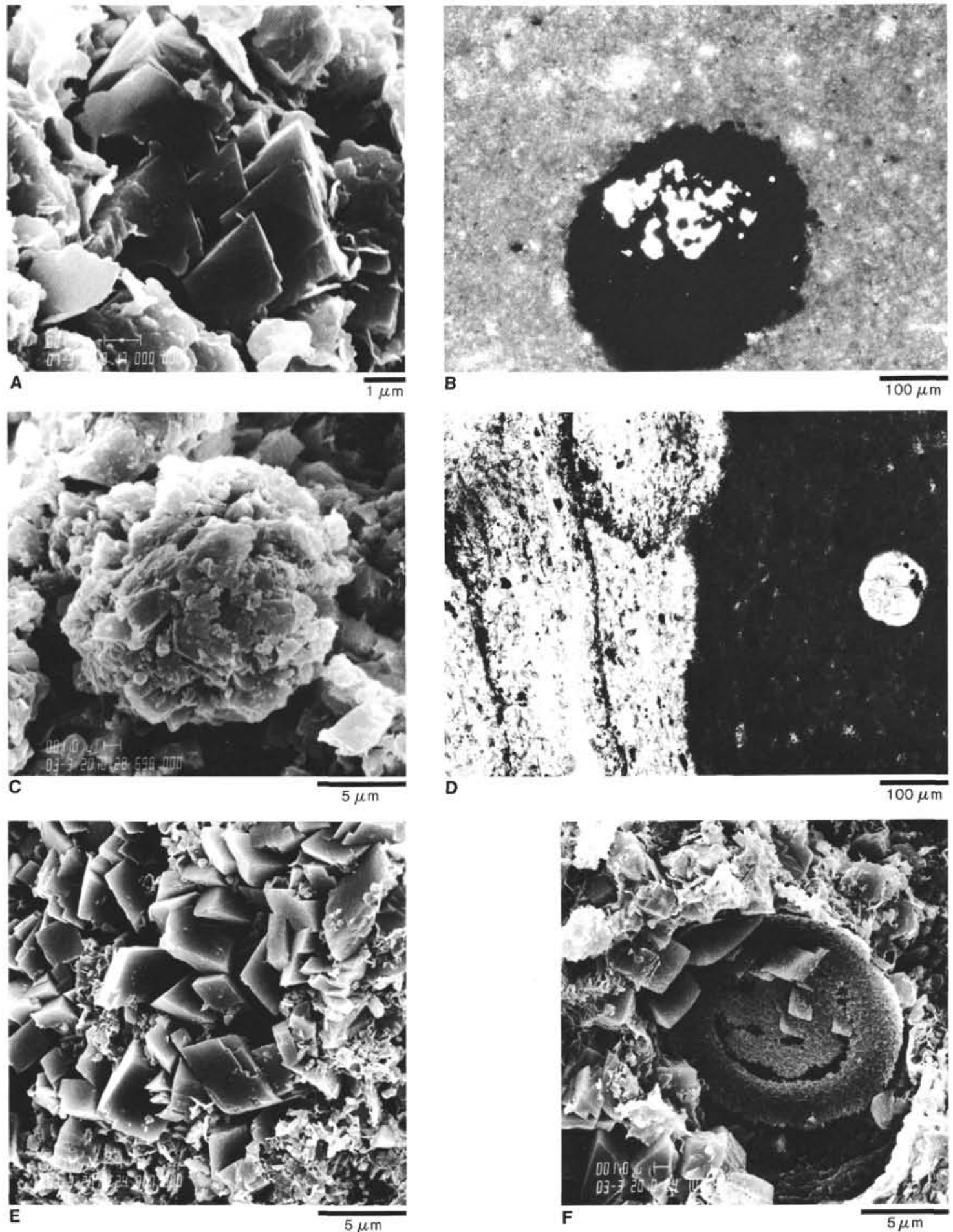

Figure 8. Photomicrographs and scanning electron micrographs of siderite nodules. A. Well-developed manganosiderite rhombohedra in a lower Pliocene authigenic carbonate nodule. Composition is $\mathrm{Fe}>\mathrm{Mn}$, with traces of $\mathrm{Ca}$ and $\mathrm{Mg}$. Sample 603-15-5, $85 \mathrm{~cm}$ (SEM 1619/12, 7000×). B. Relict framboidal pyrite concretion in siderite nodule, Sample 603-46-2, 56-50 cm. C. Spherical concretion (possibly sideritized radiolarian?) in siderite nodule, Sample 603-46-2, 56-60 cm (SEM 1623/9, 3000×). D. Siderite concretion (dark matrix, right-hand side) with well-preserved small foraminifer. The nodule is surrounded by hemipelagic quartz-bearing porcellaneous radiolarian claystone. Sample 603-50-3, $122-124 \mathrm{~cm}$. E. Scanning electron micrograph of same specimen in D, showing ideally developed siderite rhombs (Fe $\gg \mathrm{Mn}$, traces of $\mathrm{Mg}$ ) replacing the original claystone (note relict clay minerals (SEM 1624/2, 3000 X). F. Same nodule as $\mathrm{D}$ and $\mathrm{E}$; note siderite rhombs growing on (and partly replacing) corroded coccolith and replacing smectite flakes (SEM 1624/3, 3000 $\times$ ). 

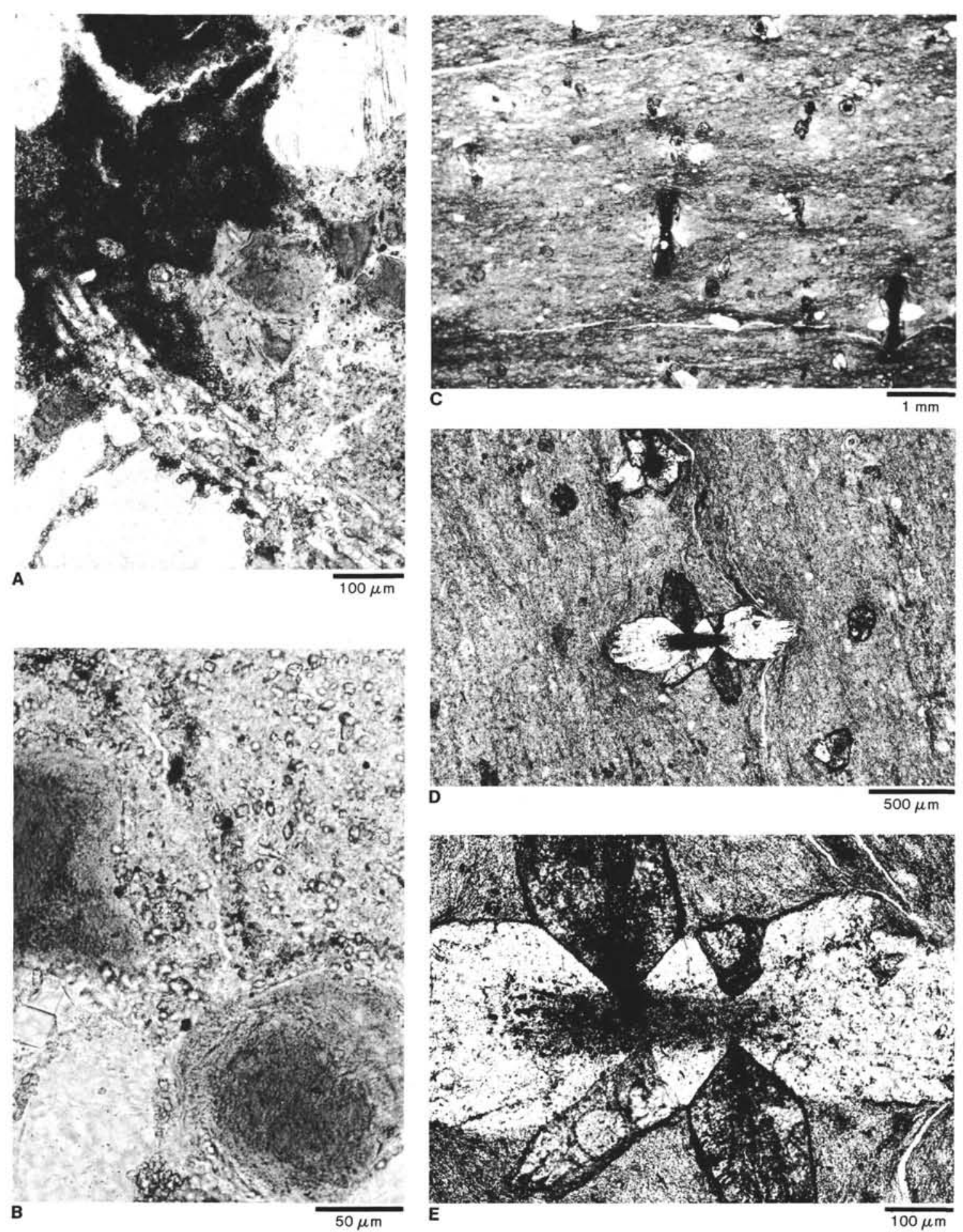

Figure 9. Photomicrographs of manganosiderite and rhodochrosite. A. Turbiditic glauconite-rich quartz sandstone, first cemented by manganosiderite that was later replaced by dense opal cement, Sample 603B-5,CC. B. Detail of A, showing relict manganosiderite rhombs in opal cement with quartz and glauconite grains. C, D, F. Scattered rhodochrosite crystals and fibroradiated spherulitic twins in a Cenomanian to Coniacian zeolite-quartz-bearing claystone, Sample 603B-21-4, $121-122 \mathrm{~cm}$. 


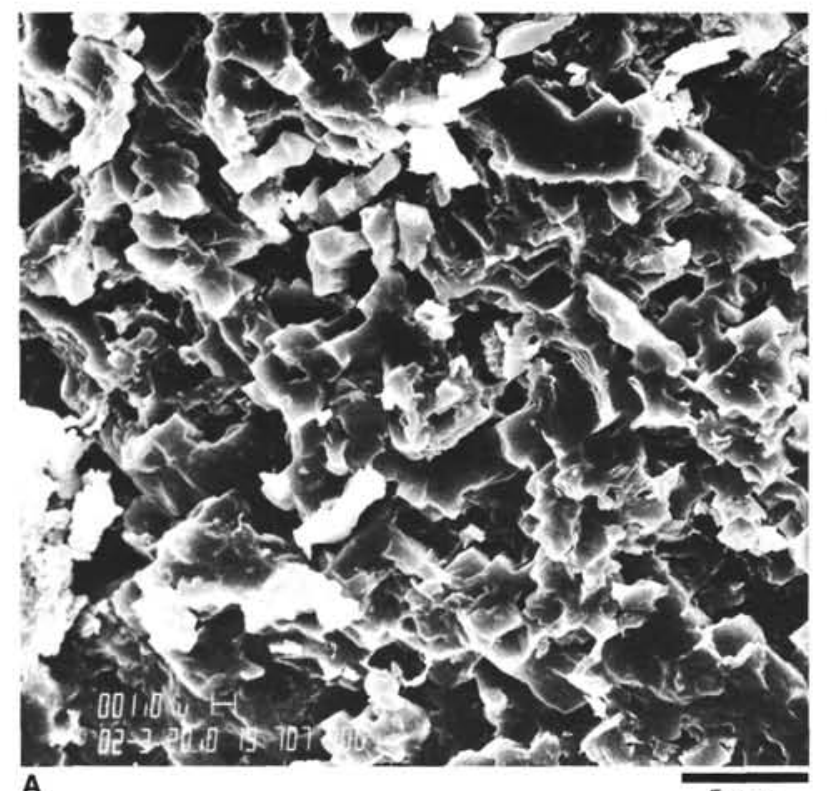

A
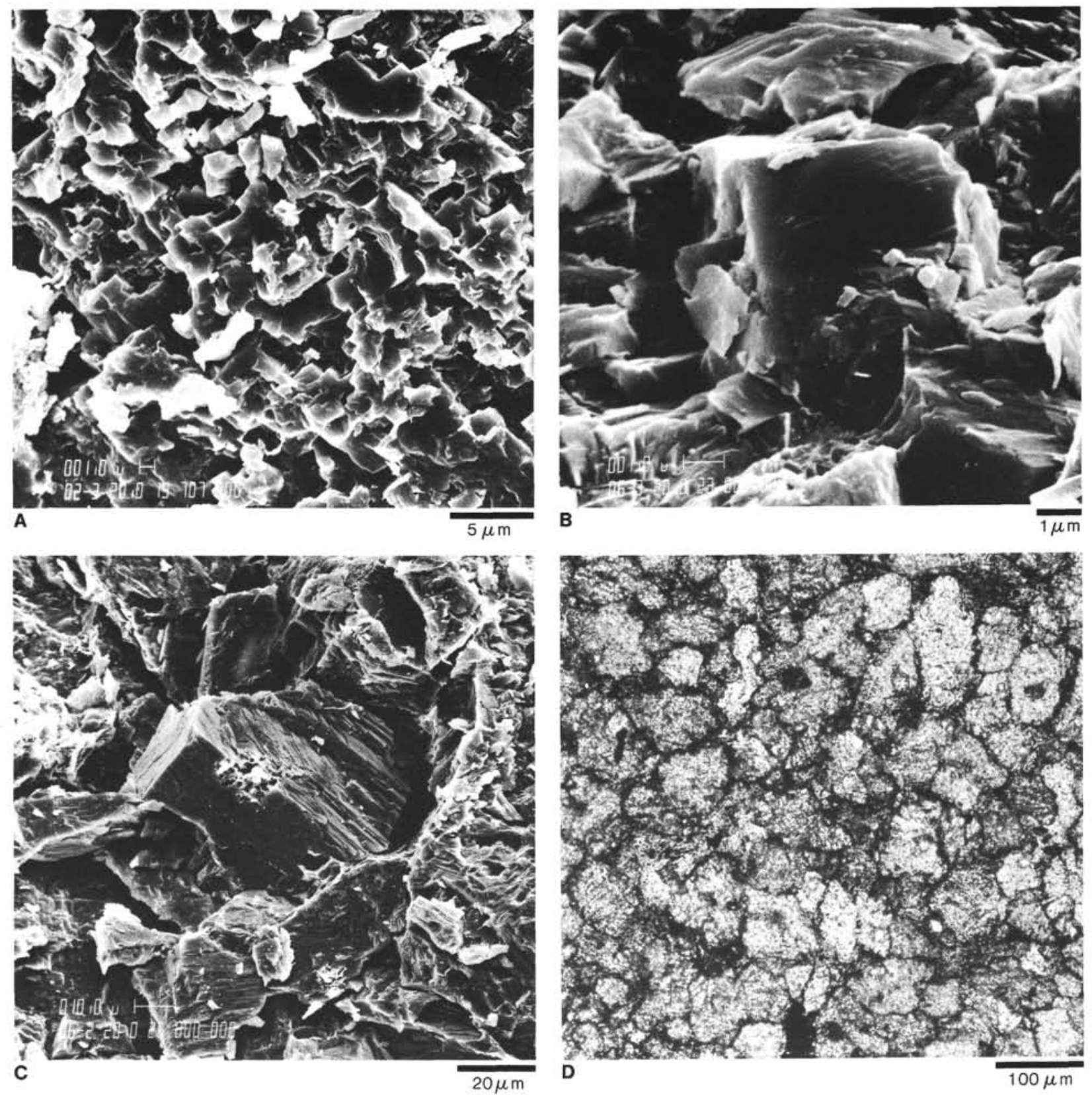

Figure 10. Photomicrographs and scanning electron micrographs of rhodochrosite and manganosiderite. A. Rhodochrosite rhombs in radiolarian-rich porcellaneous claystone, Sample 603B-21-4, 121-122 cm (SEM 1624/12, 2000 X). B. Large rhodochrosite rhombs in Cenomanian to Coniacian rhodochrosite nodule, Sample 603B-29-2, $41 \mathrm{~cm}$ (SEM 1920/4, 6000 ×). C. Large manganosiderite rhombs in Aptian to Albian Fe-Mn carbonate nodule, Sample 603B-37-2, 0-5 cm (SEM 1620/6, 600 X). D. Photomicrograph of same specimen as $\mathrm{C}$, showing cobblestonelike mosaic of late-diagenetic, sparitic, anhedral to subhedral manganosiderite cement.

of biogenic $\mathrm{CaCO}_{3}$ by the lowering of $\mathrm{pH}$ during the decay of organic matter may also contribute to raising the alkalinity.

\section{ISOTOPIC RESULTS}

Figure 11 shows a schematic model of diagenetic zones in anoxic sediments, as well as hypothetical trends in isotopic composition of diagenetic carbonates formed at various depths (after Claypool and Kaplan, 1974; Irwin et al., 1977; Irwin, 1980; Pisciotto and Mahoney, 1981; Keltz and McKenzie, 1980, 1982). Four diagenetic zones are generally recognized, from top to base: (1) a bacterial oxidation zone, (2) a bacterial sulfate reduction zone, (3) a carbonate reduction and fermentation zone, and (4) a deep zone in which thermal processes cause the degradation of organic matter. Shallow, aerobic, microbial oxidation and anaerobic sulfate reduction can result in negative $\delta^{13} \mathrm{C}$ values as low as $-21 \%$. Positive $\delta^{13} \mathrm{C}$ carbonate values (to $+15 \%$ ) can be found below this zone, where $\mathrm{CH}_{4}$ generation by $\mathrm{CO}_{2}$ reduction, occurring after dissolved sulfate has disappeared, results in residual ${ }^{13} \mathrm{C}$-rich bicarbonate. Thermocatalytic decar- 


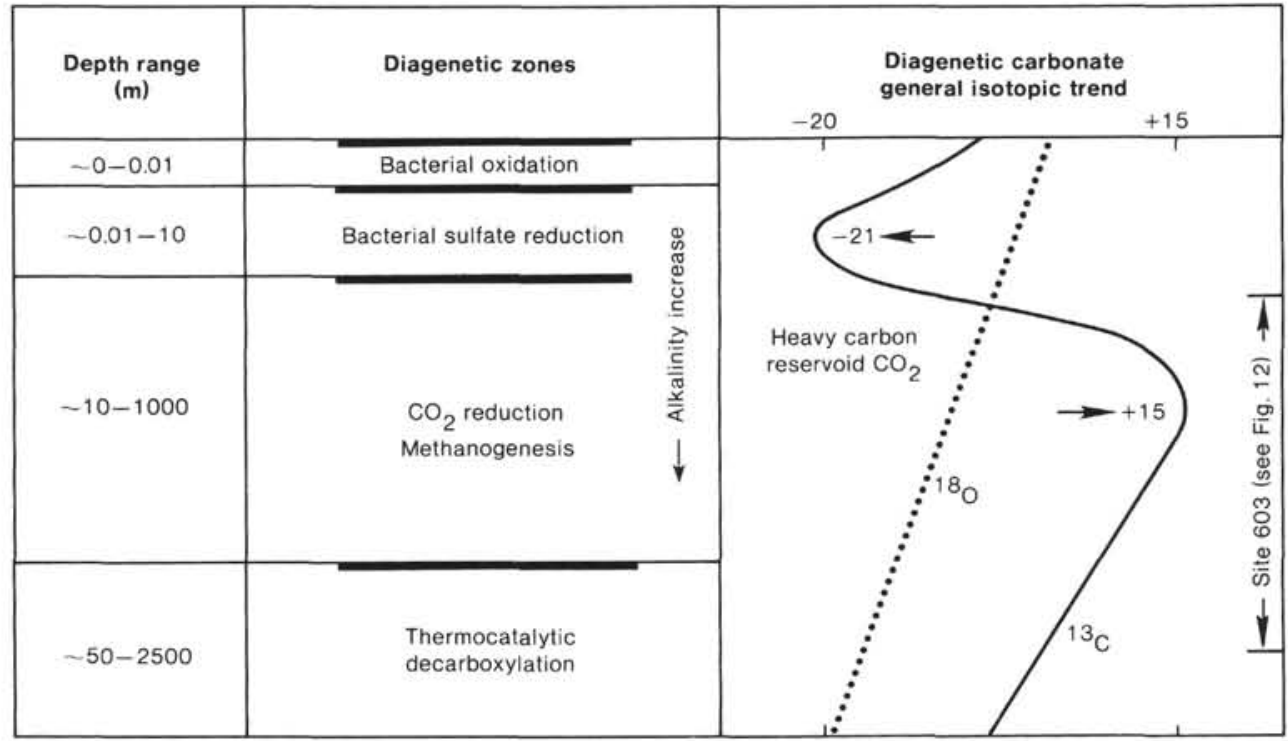

Figure 11. Schematic model of diagenetic zones in anoxic sediments and hypothetical trends in isotopic composition of authigenic carbonates (modified after Kelts and McKenzie, 1982; based on data of Claypool and Kaplan, 1974; Irwin et al., 1977; Irwin, 1980; and Pisciotto and Mahoney, 1981). Arrows indicate characteristic trends.

boxylation at greater depth can result in isotopically light $\mathrm{CO}_{2}$ and, therefore, the $\delta^{13} \mathrm{C}$ of authigenic carbonates may decrease again as depth increases. Alternatively, the $\delta^{13} \mathrm{C}$ carbonate values may decrease with increasing depth when a closed-system gas reservoir is depleted in ${ }^{13} \mathrm{C}$ by isotopic fractionation between the dissolved $\mathrm{CO}_{2}$ and the precipitated carbonate (Kelts and McKenzie, 1982).

Figure 12 shows the carbon and oxygen isotope composition of the $\mathrm{Fe}-\mathrm{Mn}$ carbonate nodules investigated. The $\delta^{13} \mathrm{C}$ values show a more or less systematic increase from $-7.9 \%$ at a depth of $\sim 330 \mathrm{~m}$ to $+1.7 \%_{0}$ at $\sim 740$ $\mathrm{m}$. The $\delta^{13} \mathrm{C}$ values then decrease again and reach their most negative value, $-12.9 \%$, at a depth of $1160 \mathrm{~m}$. The $\delta^{18} \mathrm{O}$ values systematically decrease from values in the range of +5 to $6 \%$ (at 300 to $500 \mathrm{~m}$ ) to $-1.2 \% 0$ (at $1160 \mathrm{~m}$ ). Figure 12 and Table $1 \mathrm{~B}$ show that each siderite nodule has a more or less homogeneous isotopic composition. The maximum variation in $\delta^{13} \mathrm{C}$ between the rim and the core of an individual nodule is $1.2 \%$. The $\delta^{18} \mathrm{O}$ values show no variations whatsoever among different zones of the same nodule.

\section{$\delta^{13} \mathrm{C}$ Values}

The systematic variations in the $\delta^{13} \mathrm{C}$ values of the diagenetic siderites investigated during this study (Fig. 12) are very similar to the hypothetical trend in isotopic composition (Fig. 11). Although the $\delta^{13} \mathrm{C}$ values of the siderites occurring within the zone of maximum methane abundance at $700-800 \mathrm{~m}$ burial depth are not so positive as shown in Figure 11 (we found $\delta^{13} \mathrm{C}$ values only up to $+1.7 \%$ only, whereas Figure 11 shows maximum values of $+15 \% 0$ ), it is likely that the shift toward more positive $\delta^{13} \mathrm{C}$ values in the siderites between 330 and $780 \mathrm{~m}$ depth is the result of methane formation by $\mathrm{CO}_{2}$ reduction. During this process, $\mathrm{H}^{12} \mathrm{CO}_{3}{ }^{-}$is preferentially removed by microbial metabolic processes, re- sulting in an enrichment of ${ }^{13} \mathrm{C}$ in the residual $\mathrm{HCO}_{3}{ }^{-}$. The actual $\delta^{13} \mathrm{C}$ value of diagenetic carbonate depends upon the amount of $\mathrm{CO}_{2}$ reduced (Claypool and Kaplan, 1974). Claypool and Kaplan (1974) noted that the most commonly observed change in the $\delta^{13} \mathrm{C}$ of dissolved bicarbonate in DSDP sediments during the early stage of methane production is from about $-23 \% 0$ to about $+5 \%$. The shift in the $\delta^{13} \mathrm{C}$ values of our samples falls into this range.

The homogeneous $\delta^{13} \mathrm{C}$ values within individual siderite nodules indicate that our nodules did not continue to grow over an extended period of time. Therefore, the depletion in ${ }^{13} \mathrm{C}$ in the depth interval between 800 and $1200 \mathrm{~m}$ might be due to the addition of isotopically light $\mathrm{CO}_{2}$ at a faster rate than $\mathrm{CO}_{2}$ was removed by $\mathrm{CH}_{4}$ production (Claypool and Kaplan, 1974). This explanation is more likely than the one which postulates that depletion in ${ }^{13} \mathrm{C}$ occurred in a closed-system gas reservoir by isotopic fractionation between the dissolved $\mathrm{CO}_{2}$ and the precipitated carbonate (Kelts and McKenzie, 1982).

If the nodules had nucleated at a lower burial depth and had continued to grow during burial (i.e., during a variety of geochemical conditions), they would have passed the $\delta^{13} \mathrm{C}$ diagenetic pathway shown in Figure 11 and, consequently, in the case of carbonate formation during early stages of methanogenesis, their cores should have lower $\delta^{13} \mathrm{C}$ values than their rims (R. Hesse, personal communication). Since we did not detect any isotopic zonation within the nodules (Table 1B), we assume that they formed in the same geochemical zone in which they occur today. This means that the $\delta$ values roughly reflect geochemical conditions at the present burial depth. This agrees with the observations of Wada and Okada (1983), who also found that magnesian calcite, Mn-calcite, dolomite, and rhodochrosite nodules from the Japan Trench were authigenically formed near the position where they are found. 


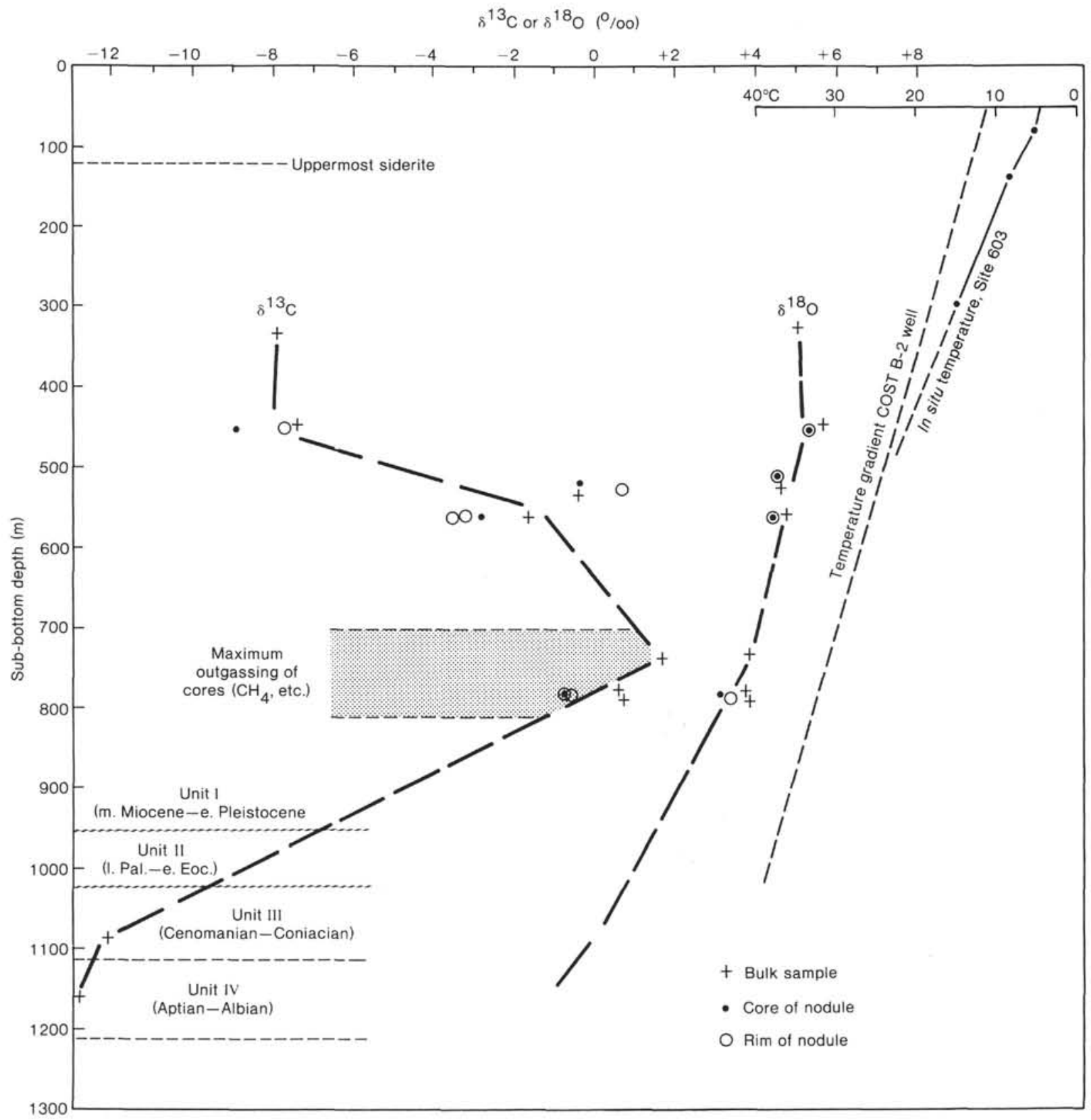

Figure 12. Carbon and oxygen isotopic composition of Fe-Mn carbonate nodules at Site 603 versus depth in hole (cf. Fig. 1). Measured in situ temperatures of Site 603 from Site 603 site chapter, this vol.; temperature gradient of COST B-2 well (from Scholle, 1977) for comparison. Note that horizontal temperature scale refers only to measured in situ temperatures and is not calculated from $\delta^{18} \mathrm{O}$ values.

\section{$\delta^{18} \mathbf{O}$ Values}

The $\delta^{18} \mathrm{O}$ values of the siderite samples (Fig. 12) decrease with depth and follow the hypothetical $\delta^{18} \mathrm{O}$ trend shown in Figure 11. The negative $\delta^{18} \mathrm{O}$ shift probably reflects the increase in temperature with depth. However, the $\delta^{18} \mathrm{O}$ values of interstitial waters can also vary: many $\delta^{18} \mathrm{O}$ profiles of interstitial waters at DSDP sites begin with $0 \%$ at the sediment/water interface and show an average depletion gradient of about $-0.5 \%$ per $100 \mathrm{~m}$ of burial depth (Lawrence et al., 1975). This holds true for sediments rich in volcanogenic material or for diffusion-controlled profiles (R. Hesse, personal communi- cation, 1985), neither of which are likely to be applicable at Site 603 .

Figure 12 shows a variable gradient of $\delta^{18} \mathrm{O}$ versus depth: the $\delta^{18} \mathrm{O}$ values of siderites found in the depth interval between 300 and $800 \mathrm{~m}$ (Unit I) are positive and differ only by 2 to $3 \%$; the siderites in the depth range of 1085 to $1160 \mathrm{~m}$, however, have $\delta^{18} \mathrm{O}$ values 4 to $5 \%$ lower than the siderites found between 740 to $780 \mathrm{~m}$ depth. To our knowledge, the equilibrium-fractionation factors of siderite have not yet been established; the isotopic composition of the pore water from which the carbonates precipitated is also unknown. Using the relationship for calcite and water (Epstein et al., 1953), the 
formation temperatures of the siderites can be roughly estimated from their $\delta^{18} \mathrm{O}$ values. The siderites in the interval 330 to $780 \mathrm{~m}$ have estimated formation temperatures of less than $5^{\circ} \mathrm{C}$. The siderites between 1085 and $1160 \mathrm{~m}$ depth, however, have formation temperatures around $20^{\circ} \mathrm{C}$ (assuming $\delta^{18} \mathrm{O} \mathrm{H}_{2} \mathrm{O}=0 \%$ ). Kelts and McKenzie (1982) suggested that carbonates nucleate at a certain burial depth and then continue to grow with increasing burial. Thus the calculated temperatures would not be in situ temperatures strictly speaking, since only the outermost rim of the siderites represents the actual in situ environment. However, the isotopic homogeneity of the individual nodules (Table 1B) indicates that this does not hold true for the carbonate nodules investigated during this study. In particular, the $\delta^{18} \mathrm{O}$ values do not show any variation within a single nodule. Thus, the temperatures calculated $\left(0-20^{\circ} \mathrm{C}\right)$ should be correct, if the assumption is right that the pore water had a $\delta^{18} \mathrm{O}$ value of $0 \%$. The actual in situ temperatures measured at Site 603 by thermoprobe (Site 603 chapter, this volume) are indeed considerably higher than those calculated from the $\delta^{18} \mathrm{O}$ values (Fig. 11). This indicates that the isotopic composition of the pore water during siderite formation was $>0 \%$.

\section{CONCLUSIONS}

Tentatively, we suggest the following sequence of formation for sulfides and authigenic carbonates:

1. Pyrite was precipitated in the zone of bacterial sulfate reduction a few centimeters to a few tens of meters below the seafloor, where sulfate is reduced to sulfide and organic matter oxidized by microbial activity. Pyrite, which occurs with variable abundance at depths between $100 \mathrm{~m}$ and the base of Site 603 , was mainly formed during early diagenesis at shallow burial depths. Pyrite remained stable during the subsequent precipitation of siderite nodules (Plate 4B).

2. According to XRD analysis, the youngest and uppermost authigenic carbonate nodules consist of manganosiderite and poorly ordered dolomite (Table 1A; Fig. 1). Dolomite (which could not be identified by elemental analysis under the SEM) is commonly the first early diagenetic carbonate to be precipitated between a burial depth of a hundred to a few hundred meters, where $\mathrm{Mg}^{++}$(and $\mathrm{Ca}^{++}$) concentrations in the pore water have their maximum (see also Tassé and Hesse, 1984).

3. All carbonate nodules below $500 \mathrm{~m}$ burial depth in the Neogene hemipelagic claystones consist only of siderite (with $\mathrm{Fe} \gg \mathrm{Mn}$ and only traces of $\mathrm{Mg}$ and $\mathrm{Ca}$ ) or manganosiderite (Table 1). The oxygen isotope composition of the Fe-Mn carbonate nodules proves their marine origin, and the carbon isotope composition suggests that they were precipitated during burial of a few hundred meters and were affected by $\mathrm{CO}_{2}$ reduction during methanogenesis (Fig. 11). The measured $\delta^{13} \mathrm{C}$ values increase systematically with sub-bottom depth from $-8.9(450 \mathrm{~m})$ to $+1.7 \%(740 \mathrm{~m})$, probably because of the preferential removal of ${ }^{12} \mathrm{CO}_{2}$ during the formation of bacterial methane. The maximum of methane (and $\mathrm{CO}_{2}$ ) outgassing in our cores (Site 603 chapter, this vol- ume) also coincides with the most positive $\delta^{13} \mathrm{C}$ values (Fig. 12). There is little evidence to support a $\mathrm{CO}_{2}$ source from the dissolution of biogenic $\mathrm{CaCO}_{3}$ as precursor of siderite: Site 603 passed through the CCD about $6 \mathrm{Ma}$ ago, but the uppermost siderite occurs at a sub-bottom depth of $120 \mathrm{~m}$, where $\mathrm{CaCO}_{3}$ contents still range between 10 and $25 \%$. A few relict coccoliths even occur in the facies of Subunit IC below the CCD. The fact that calcareous nannoplankton is sometimes preferentially preserved in burrows suggests that, near the $\mathrm{CCD}, \mathrm{CaCO}_{3}$ may on occasion be locally preserved below the sediment/water interface, if it is rapidly removed by burrowing organisms (S. Wise, personal communication, 1983). It is interesting to note that these coccoliths have been partly replaced by the authigenic siderite rhombs at the expense of calcite (Fig. 8F). The original manganosiderite cement of the sandstone Sample 603B-5,CC (Fig. 9A, B) might be due to sporadic supply of carbonate material by turbidity currents down into an environment below the CCD and the subsequent replacement of calcite by manganosiderite.

Therefore the main $\mathrm{CO}_{2}$ source for the authigenesis of carbonates was the microbiological degradation of organic matter during burial, resulting from $\mathrm{CO}_{2}$ reduction by the onset of methane production (Fig. 11). Whereas scattered siderite crystals occur in most hemipelagic claystones of Unit I, siderite nodules were preferentially precipitated in the microenvironment of burrows or fecal pellet concentrations which were rich in organic matter. Yellowish white siderite concretions often mimic a variety of much earlier formed bioturbation structures (Figs. 5, 6). Siderite was also rarely precipitated as cement in turbiditic sandstones, possibly because these layers are more permeable to migrating pore fluids.

Since there is no consistent downhole increase of nodule size and no isotopic variation between core and rim, we assume that the nodules grew during the past few million years and represent more or less the geochemical conditions of the present burial depth.

4. Rhodochrosite $\left(\mathrm{MnCO}_{3}\right)$ occurs only in the Paleogene to Upper Cretaceous Units II and III, at a burial depth between 1015 and $1085 \mathrm{~m}$. According to the general $\delta^{13} \mathrm{C}$ trend of diagenetic carbonates (Fig. 11) toward more negative values, the analyzed sample possibly belongs to the zone where $\mathrm{CO}_{2}$ contributions from thermocatalytic processes have already occurred (Fig. 11). In the variegated claystones of Unit III, manganese nodules characteristically occur in the reddish brown, welloxidized facies and rhodochrosite nodules in the greenish gray, more organic-carbon-rich, partially reduced facies. Apparently Mn oxides were the precursors of the $\mathrm{Mn}$ carbonates which formed after reduction of $\mathrm{Mn}^{4+}$ to $\mathrm{Mn}^{++}$with decreasing $\mathrm{Eh}$. The incipient growth of individual crystals and small (3-mm diameter) nodules were both observed (Table 1). The considerably larger size of the rhodochrosite rhombs, as compared with the cryptocrystalline Tertiary (mangano)-siderite, suggests a later diagenetic origin for the rhodochrosite.

5. A late diagenetic micro- to macrocrystalline manganosiderite nodule was found in the Aptian-Turonian 
black carbonaceous claystones (Unit IV). Again, its negative $\delta^{13} \mathrm{C}$ value suggests a contribution of $\mathrm{CO}_{2}$ derived from thermocatalytic processes.

\section{ACKNOWLEDGMENTS}

We are very grateful to E. Faber (BGR) for his permission to use BGR's mass spectrometer for the isotopic analyses and to H. Rösch (BGR) for several X-ray diffraction analyses. H. Schmitz (BGR) helped with the mineralogical description of the rhodochrosite crystals. E. Knickrehm (BGR) offered his expert assistance at the ETEC-Autoscan scanning electron microscope. The Leg 93 chief scientists and sedimentologists contributed valuable ideas during the shipboard examination of the cores and samples. M. Kastner (La Jolla) discussed with us the siderite problem. We thank H. Rösch (Hannover), V. Marchig (Hannover), P. Stoffers (Heidelberg), G. Glasby (Wellington), D. Dunn (Hattiesburg), M. Meylan, and in particular R. Hesse (Montreal) for a critical review of this paper.

\section{REFERENCES}

Asquith, S. M., 1979. Nature and origin of the lower continental rise hills off the east coast of the United States. Mar. Geol., 32:165190.

Benson, W. E., Sheridan, R. E., et al., 1978. Site 391: Blake-Bahama Basin. In Benson, W. E., Sheridan, R. E., et al., Init. Repts. DSDP, 44: Washington (U.S. Govt. Printing Office), 153-336.

Berger, W. H., and von Rad, U., 1972. Cretaceous and Cenozoic sediments from the Atlantic Ocean. In Hayes, D. E., Pimm, A. C., et al., Init. Repts. DSDP, 14: Washington (U.S. Govt. Printing Office), 787-954.

Berner, R. A., 1971. Principles of Chemical Sedimentology: New York (McGraw Hill), pp. 192-200.

Claypool, G. E., and Kaplan, I. R., 1974. The origin and distribution of methane in marine sediments. In Kaplan, I. R. (Ed.), Natural Gases in Marine Sediments. Marine Science, 3: New York (Plenum Press), 99-139.

Einsele, G., and von Rad, U., 1979. Facies and paleoenvironment of Lower Cretaceous sediments at DSDP Site 397 and in the Aaiun Basin (Northwest Africa). In von Rad, U., Ryan, W. B. F., et al., Init. Repts. DSDP, 47, Pt. 1: Washington (U.S. Govt. Printing Office), 559-578.

Epstein, S., Buchsbaum, H. A., Lowenstam, H. A., and Urey, H. C., 1953. Revised carbonate-water isotopic temperature scale. Geol. Soc. Am. Bull., 64:13-1326.

Garrels, R. M., and Christ, C. L., 1965. Solutions, Minerals and Equilibria: New York (Harper and Row).

Gautier, D. L., 1982. Siderite concretions: indicators of early diagenesis in the Gammon Shale (Cretaceous). J. Sed. Petrol., 52(3):859871.
Irwin, H., 1980. Early diagenetic carbonate precipitation and pore fluid migration in the Kimmeridge clay of Dorset, England. Sedimentology, 27:577-591.

Irwin, H., Curtis, C., and Coleman, M., 1977. Isotopic evidence for source of diagenetic carbonates formed during burial of organicrich sediments. Nature, 269:209-213.

Jansa, L. F., Enos, P., Tucholke, B. E., Gradstein, F. M., and Sheridan, R. E., 1979. Mesozoic-Cenozoic sedimentary formations of the North American Basin, western North Atlantic. In Talwani, M., Hay, W. W., and Ryan, W. B. F. (Eds.), Deep Drilling Results in the Atlantic Ocean: Continental Margins and Paleoenvironment. Am. Geophys. Un., Maurice Ewing Ser., 3:1-57.

Kelts, K. R., and McKenzie, J. A., 1980. Formation of deep-sea dolomite in anoxic diatomaceous oozes. Twenty-sixth Int. Geol. Congr., Paris, France. (Abstr.)

1982. Diagenetic dolomite formation in Quaternary anoxic diatomaceous muds of Deep Sea Drilling Project Leg 64, Gulf of California. In Curray, J. R., Moore, D. G., et al., Init. Repts. DSDP, 64: Washington (U.S. Govt. Printing Office), 553-569.

Lancelot, Y., Hathaway, J., and Hollister, C. D., 1972. Lithology of sediments from the western North Atlantic, Leg 11, Deep Sea Drilling Project. In Hollister, C. D., Ewing, J., et al., Init. Repts. DSDP, 11: Washington (U.S. Govt. Printing Office), 901-949.

Lawrence, J. R., Gieskes, J., and Broecker, W. S., 1975. Oxygen isotope and cation composition of DSDP pore waters and the alternation of layer II basalts. Earth Planet. Sci. Lett., 27:1-10.

Pisciotto, K. A., and Mahoney, J. J., 1981. Isotopic survey of diagenetic carbonates, Deep Sea Drilling Project Leg 63. In Yeats, R. S., Haq, B. U., et al., Init. Repts. DSDP, 63: Washington (U.S. Govt. Printing Office), 595-609.

Scholle, P. A. (Ed.), 1977. Geological Studies on the COST No. B-2 Well, U.S. mid-Atlantic Outer Continental Shelf Area. U.S. Geol. Surv. Circular 750.

Tassé, N., and Hesse, R., 1984. Origin and significance of complex authigenic carbonates in Cretaceous black shales of the Western Alps. J. Sed. Petrol., 54:1012-1027.

Wada, H., Niitsuma, N., Nagasawa, K., and Okada, H., 1982. Deep sea carbonate nodules from the Middle America Trench area of Mexico, Deep Sea Drilling Project Leg 66. In Watkins, J. S., Moore, J. C., et al., Init. Repts. DSDP, 66: Washington (U.S. Govt. Printing Office), 453-474.

Wada, H., and Okada, H. 1983. Nature and origin of deep-sea carbonate nodules collected from the Japan Trench. In Watkins, J. S., and Drake, C. L. (Eds.), Studies in Continental Margin Geology. Am. Assoc. Pet. Geol. Mem., 34:661-672.

Date of Initial Receipt: 1 February 1985

Date of Acceptance: 4 November 1985 